\title{
Prasat Sambor as a Prototype of the Pyramidal State-Temple in Khmer Temple Construction
}

\author{
Shimoda Ichita \\ Heritage Studies Program, Graduate School of Comprehensive Human Sciences, University of Tsukuba, Ibaraki, Japan \\ Email: shimoda@heritage.tsukuba.ac.jp
}

How to cite this paper: Ichita, S. (2021). Prasat Sambor as a Prototype of the Pyramidal State-Temple in Khmer Temple Construction. Archaeological Discovery, 9, 52-83. https://doi.org/10.4236/ad.2021.91003

Received: December 30, 2020

Accepted: January 24, 2021

Published: January 27, 2021

Copyright (c) 2021 by author(s) and Scientific Research Publishing Inc. This work is licensed under the Creative Commons Attribution International License (CC BY 4.0).

http://creativecommons.org/licenses/by/4.0/

\begin{abstract}
Sambor Prei Kuk is the site of an ancient city called İçānapura, which flourished as the capital of Chenla in the late 6th early 7 th century. This capital was home to several Hindu temples that marked the start of a process of architectural evolution culminating in the spectacular architecture of the Khmer civilization, as exemplified in Angor Wat. During pre-Angkorian times before the foundation of Khmer Empire in the beginning of 9th century, religious places generally consisted of a single brick shrine, in contrast to the large and varied temple complexes that emerged later. However, current comprehensive field research in the archaeological site of Sambor Prei Kuk recorded a number of unknown brick structures and diverse temple layouts by composing several structures. Among these, three temple complexes stand out for their distinctive features: Prasat Sambor, Prasat Yeai Poeun, and Prasat Tao. These temple complexes consisted of square enclosures with a central shrine at the center and numerous other structures in the adjacent precinct, and were the prototype of the three different types of temple complexes in the Angkorian period. This article focuses on the layout of these three temple complexes to reveal the fundamental components and principle layout of temple complexes in the early stage of development and illustrate the progression to more complexities in temple construction in the later period. Based on the precise analysis of the dimensional layout of Prasat Sambor, along with findings from archeological surveys, it was revealed that this temple complex embodied the features of the pyramidal state-temples that served as the central religious facility of their respective periods. Additionally, from an analysis of their dimensional layout, the planning techniques for the temple complex, as well as the unit of construction measure used for planning this temple, were identified.
\end{abstract}

\section{Keywords}

Sambor Prei Kuk, Chenla, Angkor, Cambodia, Southeast Asia, Hindu Temple 


\section{Introduction}

During the 900-year period between the 7th century which formed the early kingdom in the pre-Angkorian period and the demise of the Khmer empire in 1431, around 15 pyramidal state-temples were built in Yaśodharapura, presently known as the Angkor monument site, and other locations. A representative structure of these pyramidal temple is Angkor Wat, which was constructed in the early 12th century, and another is Bayon, which was constructed during the late 12th early half of 13th century. These state-temples were constructed by the transcendent kings who were particularly successful in consolidating their authority and maintaining a unitary state. The kings who could realize the construction of these temples were limited to about 10 rulers in the pre-Angkorian period and about 30 rulers in Angkorian period.

The kings who succeeded the throne of Khmer empire had many different duties to discharge to preserve and enhance the state, but three royal duties were considered particularly crucial: executing public works such as water management and transport infrastructure, building temples to ancestral deities including the ruler's predecessors, and building state-temples that symbolized royal authority.

When it came to state-temples, however, few rulers ever built them due to the sizable labor force required for their construction. Among the series of statetemples, Prasat Bakong, built in the late 9th century, is notable for being the first to fully adopt a large, pyramidal structure. However, this design was already present, albeit on a smaller scale, in Ak Yum, which was built in the 8th century. Even earlier examples appear in the site of Sambor Prei Kuk, which served as a royal capital in the early 7th century. Several temple complexes were consisted of multiple shrines and square enclosures around a main shrine in the center of the precinct.

The Sambor Prei Kuk complex is located within Kampong Thom Province, Kingdom of Cambodia, about $140 \mathrm{~km}$ southeast of Angkor Wat (Figure 1). The eastern part of the site forms a temple zone consisting of clusters of brick structured temples. The western part forms a moated city zone that is bordered by a moat running around its north, west, and south sides. The site in and around the city zone preserved many still-standing brick structures and remnants of civil engineering works. In 2017, the temple zone was inscribed in the UNESCO World Heritage list in recognition of the historic value. This ancient city was identified as Iç̧ānapura, the capital of Chenla, based on Chinese sources and inscriptions which were discovered in this archaeological site. These inscriptions, along with the aesthetic style of the deity statues and brick architecture, and the various archeological evidence, suggest that most of the main temples predate the Angkorian period and had remained in use during later periods (Shimoda \& Shimamoto, 2012; Shimoda et al., 2015). Many brick temples are well preserved in the temple zone, including three temple complexes situated close together: Prasat Sambor (M20), Prasat Yeai Poeun (M24), and Prasat Tao (M26). In addition, 


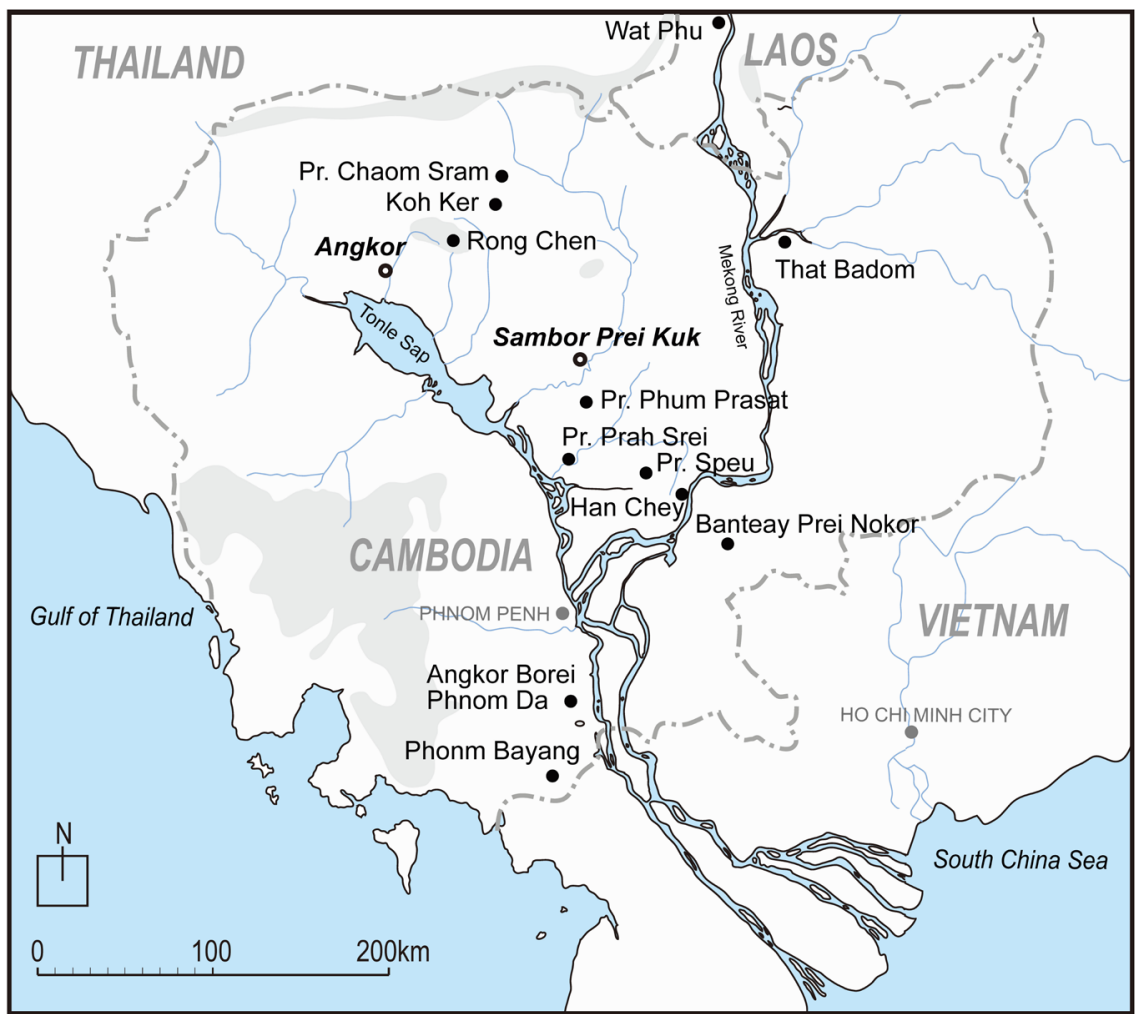

Figure 1. Location of the Sambor Prei Kuk and major Pre-Angkorian temple sites.

many temple complexes which were composed of multiple brick structures were recorded in the Sambor Prei Kuk archaeological site. Prasat Sambor features the most expansive temple precinct complex, and has been the focus of many archeological and measurement surveys.

The objectives of this article are to clarify several issues by analyzing the composition of the temple complex in the pre-Angkorian era as follows:

1) To clarify the diversity of the composition of the temple complex in preAngkor which was the earliest stages of the classical Angkor period.

2) To clarify the differences and features of three large temple complexes which were composed of multiple shrines and enclosures in Sambor Prei Kuk.

3) To clarify the significant status of Prasat Sambor as the prototype of pyramidal state-temples which were representing each period of the classical Angkor.

4) To identify the planning technique and the unit of construction measurement used for designing Prasat Sambor based on a precise survey.

5) To discuss the role of the temple complexes in the pre-Angkorian period for establishing the typology of significant number of subsequent temples and illustrating the chronological development of temple complexes in the later Angkorian period.

\section{Pre-Angkorian Temple Complexes}

Pre-Angkorian temples typically consisted of a single brick building. While many were built on flatlands, many others were situated in distinctive natural envi- 
ronments such as on hills and caves, reflecting the indigenous beliefs in each region. Although it was rare for a temple to consist of a cluster of structures in the pre-Angkorian period, there are some examples of complex temple compounds or adjacently situated shrines as described below.

Two temple sites, Preah Theat Thom and Preah Theat Toch in Banteay Prei Nokor are enclosed in a large square moat, consist of adjacently situated brick shrines (Parmentier, 1927) (Figure 1). In Preah Theat Thom, today there remain two brick shrines arranged on a north-south axis. A third shrine once stood along this axis suggesting that the complex originally formed what is known as an "architectural triad." In Preah Theat Toch, only one shrine still stands today, but this location was likely home to a temple complex given that the lower part of several structures are present nearby along with mounds of sandstone and brick material. Prasat Speu and Thnom Pdei both feature a pair of adjacent brick shrines. The best preserved of the pre-Angkorian brick shrines, Prasat Prah Srei and Prasat Phum Prasat, are dotted with brick mounds and sandstone elements around the brick shrines suggesting they were once part of a temple complex comprising multiple shrines.

A relatively large number of the structures are situated near the banks of Mekong River, and thought to have been a key trading route in the pre-Angkorian period. One of these sites is Han Chey, located about $20 \mathrm{~km}$ northeast of Kampong Cham. This site features pre-Angkorian brick and sandstone structures, both located on a small hill and composing a complex. Another example is That Badom, located in Stung Treng. This site was likely home to a temple complex consisting of a cluster of 15 shrines.

Additionally, the remains of six brick buildings were identified among the ruins of the ancient city of Shreshtapura on the west bank of the Mekong River. This location lies on the east side of Vat Phou, once a pre-Angkorian capital city (Santoni \& Hawixbrock, 1998). A further example is Angkor Borei, serving as a stronghold of Funan, and is the Chinese name for the pre-Angkorian polity. This site features a habitation zone enclosed by an embankment and a water channel. Thirty-five mounds have been identified in this zone. Fifteen of these were brick structures (Miriam, 2003), suggesting the existence of a complex religious site. Just south of Angkor Borei lies Phnom Da which also features remnants of structures. These structures were stone and rock-cut temples rather than brick ones, but they provide another example of a cluster of sacred buildings in the pre-Angkorian period.

However, none of these pre-Angkorian sites consist of a cluster of structures arranged in a clear geometric pattern within walled enclosures. An apparent exception is Phnom Bayang in Takeo Province. Situated on a plateau $310 \mathrm{~m}$ above sea level, this temple has a walled enclosure containing a central shrine and several other structures. However, this temple complex experienced multiple construction periods, and modified as many as six times from the 7th to 11th century, and the early stage in the pre-Angkorian period has yet to be defined (Mauger, 1937). 
Among the examples of pre-Angkorian temples, Sambor Prei Kuk is a distinct site with densely clustered temple complexes. Within the 134 sites which have been identified thus far, most of these are stand-alone brick structures. However, a small number of sites are complex temple arrangements with multiple structures. The layout of these complexes varies as follows (Figure 2):

a) Temples consisting of multiple shrines and other structures within two or three enclosures (M20, M24, M26)

b) Temples consisting of multiple shrines and other structures arranged in an irregular pattern within a single enclosure (M52, M78/79, M103)

c) A temple consisting of seven shrines arranged along an approximate northsouth axis with a water tank northeast of the line (M9)

d) A temple consisting of six shrines arranged along an approximate northsouth axis (M104)

e) A temple consisting of five shrines arranged in a quincunx position (M39)

f) A temple consisting of four shrines arranged along an approximate northsouth axis (M11)

g) Temples consisting of an architectural triad (three shrines arranged in an approximate north-south line) within a rectangular enclosure (M27, M75)

h) Temples consisting of an architectural triad (M13, M57, M66, M93, M94)

i) A temple consisting of three shrines arranged in a flying wedge formation within an enclosure (M31)

j) Temples consisting of two parallel shrines within an enclosure (M47/48)

k) Temples consisting of two parallel shrines (M71, M72, M82, M105)

1) Temples consisting of a single shrine in a walled or moated enclosure (M10, M45, M88, M99, M108)

In many cases, the upper part of the brick structures has been destroyed making it difficult to determine when the structures were constructed. However, it is reasonable to assume they were built during the pre-Angkorian period because

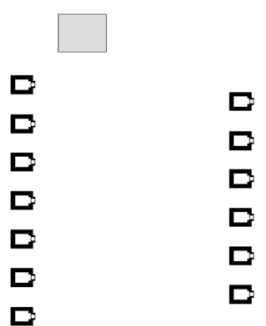

(c)

(d)

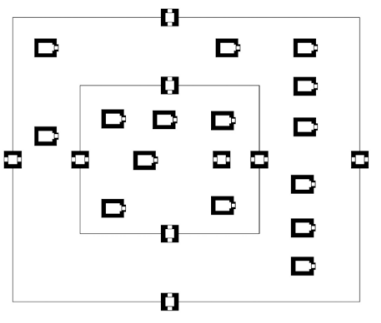

(a) M24

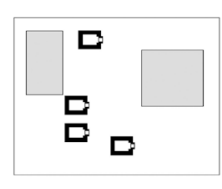

(b) M103

ㅁ
ㅁ

ㅁ
D
ㅁ

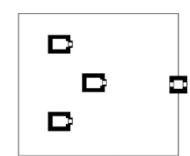

(i)

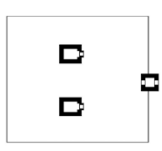

(j)

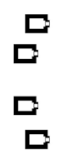

(f)

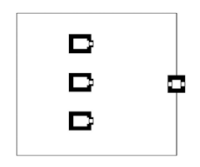

(g)

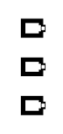

(h)

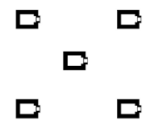

(e)

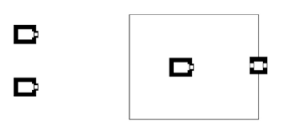

(k)

(I)

Figure 2. Types of temple complexes in Sambor Prei Kuk. 
most of the inscriptions which were found in these sites and style of the remaining part of architecture are indicative of the pre-Angkorian period. While some temple sites in particularly those located in the city zone are severely damaged, it is highly possible that a future archeological survey will discover the remains of other associated structures in the proximity of some temples. By the recent archaeological surveys, several sites, M45 and M78/79, were unearthed and consisted of brick and/or stone building and enclosure where no artifacts and structures were previously observed on the ground (Chhum et al. 2013, Kubo et al. 2016).

In summary, while the construction of temple complexes is rarely realized during the pre-Angkorian period, various type of temple complex including the large precincts with several structures appeared abundantly in Sambor Prei Kuk in the late 6th early 7th century. As such, Sambor Prei Kuk was an experiment in innovation and Khmerization that created various standard styles of the temple complex that would appear in subsequent periods in Khmer history.

\section{The Three Temple Complexes in Multiple Rectangular Enclosures in Sambor Prei Kuk}

The three large temple complexes which have two or three rectangular enclosures and several smaller scale of temples were constructed in the temple zone of Sambor Prei Kuk (Figure 3). The temple complexes feature a variety of architectural styles and ornamental shrines, in marked contrast to the brick shrines of the Angkorian period which were more generic in design with a standardized form (Shimoda \& Nakagawa, 2015). Regarding the layout of three large temple complexes, the northernmost temple is Prasat Sambor, the southernmost one is Prasat Yeai Poeun, and Prasat Tao lies between the two. Prasat Tao is offset to the west with the northeast and southeast corners of its outer enclosure adjacent to the other two complexes. This arrangement suggests that there was no initial plan to build the three complexes; instead, the two parallel complexes were constructed first and then the third complex in the center were planned and constructer later. This hypothesis is consistent with past research which derived the chronological order of the temple construction from an analysis of the chemical composition and size of the bricks (Shimoda et al., 2019). At first glance, the three complexes appear to have a similar layout, but closer inspection reveals differences between them. In this section, the composition of each complex and their features are discussed in detail.

\subsection{Composition of Prasat Sambor}

Prasat Sambor is the largest of the three main temple complexes with three enclosures. The outer enclosure forms nearly square with each side measuring approximately $389 \mathrm{~m}$. However, the outer enclosure is possibly constructed in a later period than other elements of this complex because the outer enclosure is in a poor state due to the low quality of construction work and the square plan is 


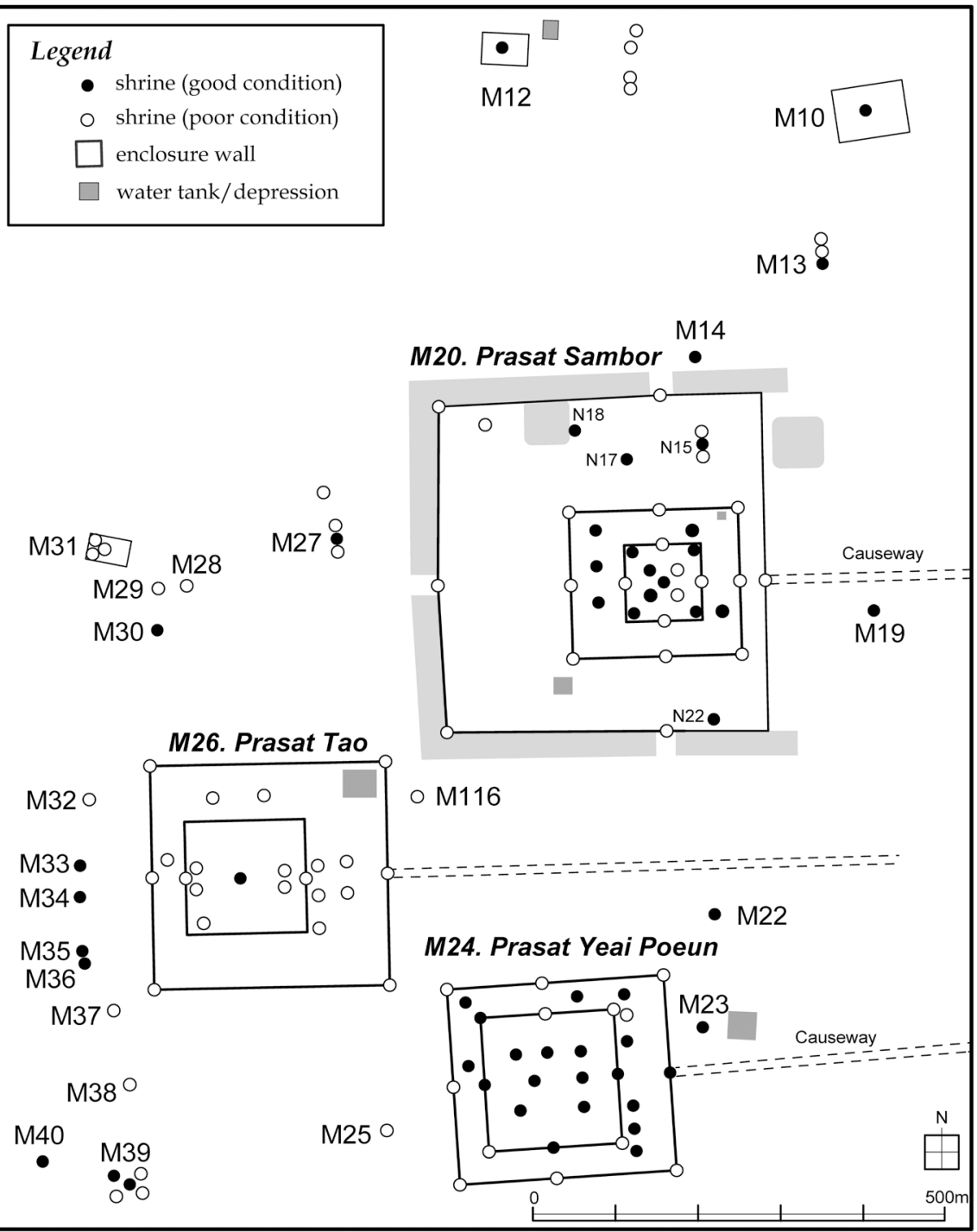

Figure 3. Distribution map of the three large temple complexes and surrounding structures in the temple zone.

markedly deformed when compared with the middle and inner enclosures. A moat measuring $45 \mathrm{~m}$ in width at the outside of the north, west, and south sides of the outer enclosure is also considered to be additional work.

Inscriptions in Prasat Sambor bear the names of two kings: Isanavarman I (r. 616-637) and Rajendravarman II (r. 944-968). Consistent with the date of these inscriptions, the style of the deity statues found in this temple are of 7 th-century or 10th-century. This evidence suggest that the temple complex was founded in the beginning of 7th century and underwent major alterations in the 10th century.

Architectural features of each element in this complex are described below, starting from the center outward of precinct. The central shrine (N1) is standing on the central terrace forming a square plan and has door openings on all four sides (Figure 4, Figure 5). To the best of our knowledge, this is the only pre-Angkorian 


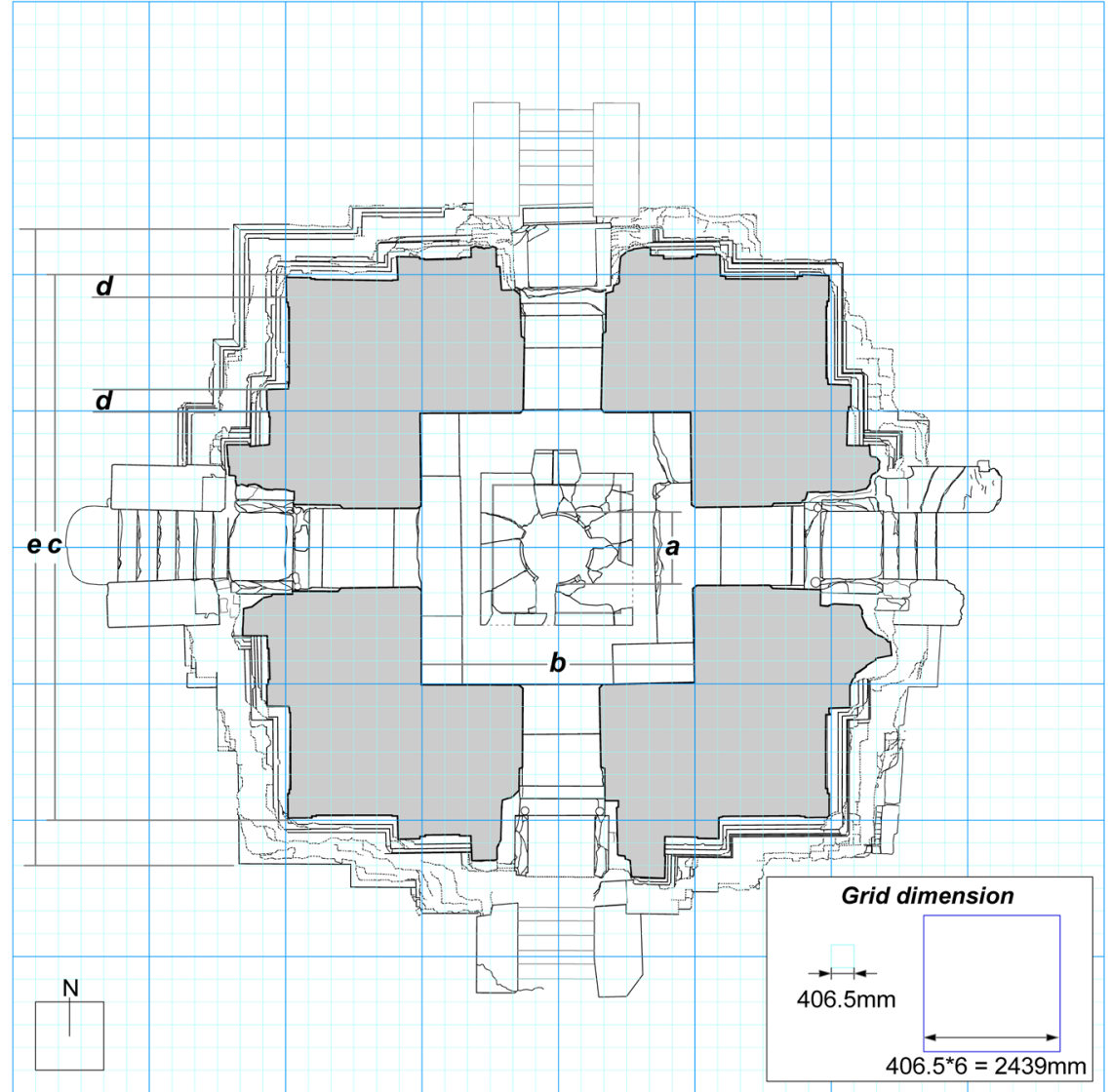

Figure 4. Plan of the central shrine (N1) of Prasat Sambor.

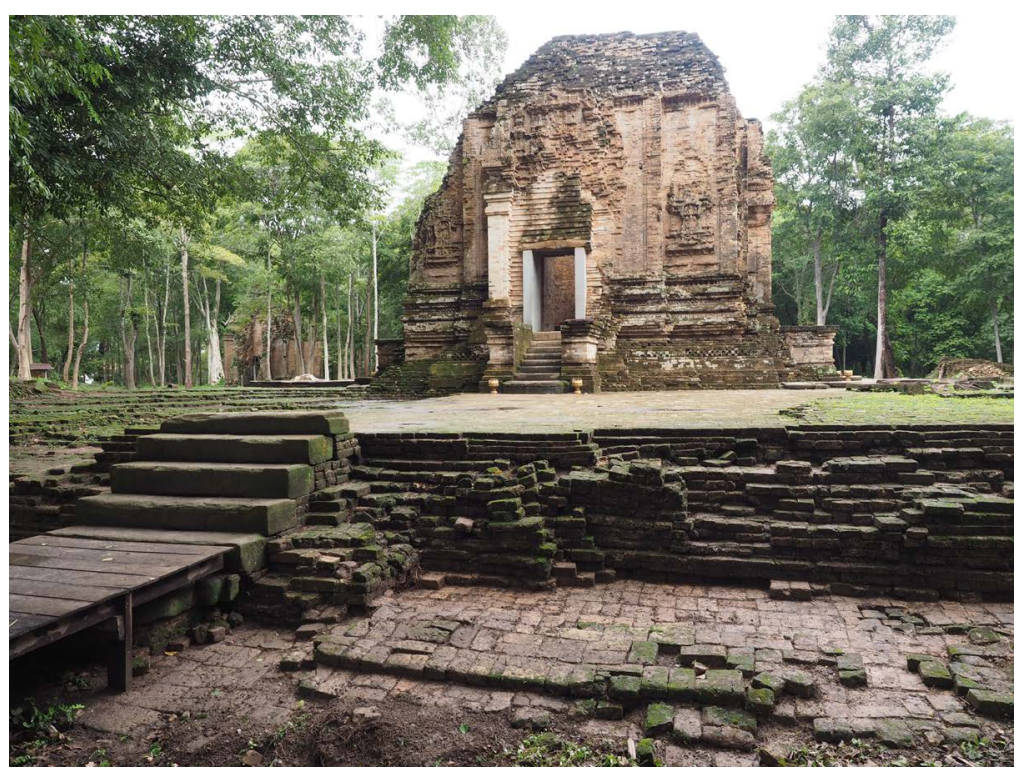

Figure 5. Central shrine (N1) standing on the central terrace of Prasat Sambor (view from north).

temple with openings on four sides. Research of scattered stone fragments revealed that a square pedestal measuring $2.7 \mathrm{~m}$ in length was installed in the 
chamber (Figure 6). At the center of this pedestal, a round mortise was observed. The diameter of this mortise is $121.5 \mathrm{~cm}$, and this mortise likely held a lingam, an aniconic form of Shiva. The main deity of the initial stage of this temple is unrevealed as of this date, but an inscription mentions that Gambhiresvara was worshipped here at the time of the additional constructions in the 10th century; Gambhiresvara probably referred to the lingam.

The central terrace surrounding the central shrine consists of a square platform elevated $1.5 \mathrm{~m}$ in height. The four sides measure roughly $40 \mathrm{~m}$, and the center of each sides has a stairway (Figure 7, Figure 8). Small four shrines (N2 N5) were probably constructed at each corner. These were likely later additional structures because the stone elements of the door frame were reused materials and the quality of brickwork is inferior to other structures. Gargoyle-like stone drainage channels are distributed around the edges of the central terrace at 24 points (six on each side). These drainages channels were made from sandstone and functioned as outlets for channeling rainwater down to the level below. This drainage system formed the prototype for the drainage system of the later pyramidal temples. A paved brick walkway, $2.1 \mathrm{~m}$ in width, was excavated around the terrace. This elevated central terrace with a staircases and drainage on all four sides and sub-shrines on all four corners is the obvious initial features of a pyramidal temple even though the height of the terrace is limited at this stage.

Eight large square pedestals were installed around the central terrace (Figure 7). Large mortises were observed on the top surface of these pedestals for holding statues in place. However, no statues, or fragments of statues, have been found for these pedestals. In many of the early-Angkorian pyramidal temples, eight subsidiary shrines of a similar design have been installed around the central

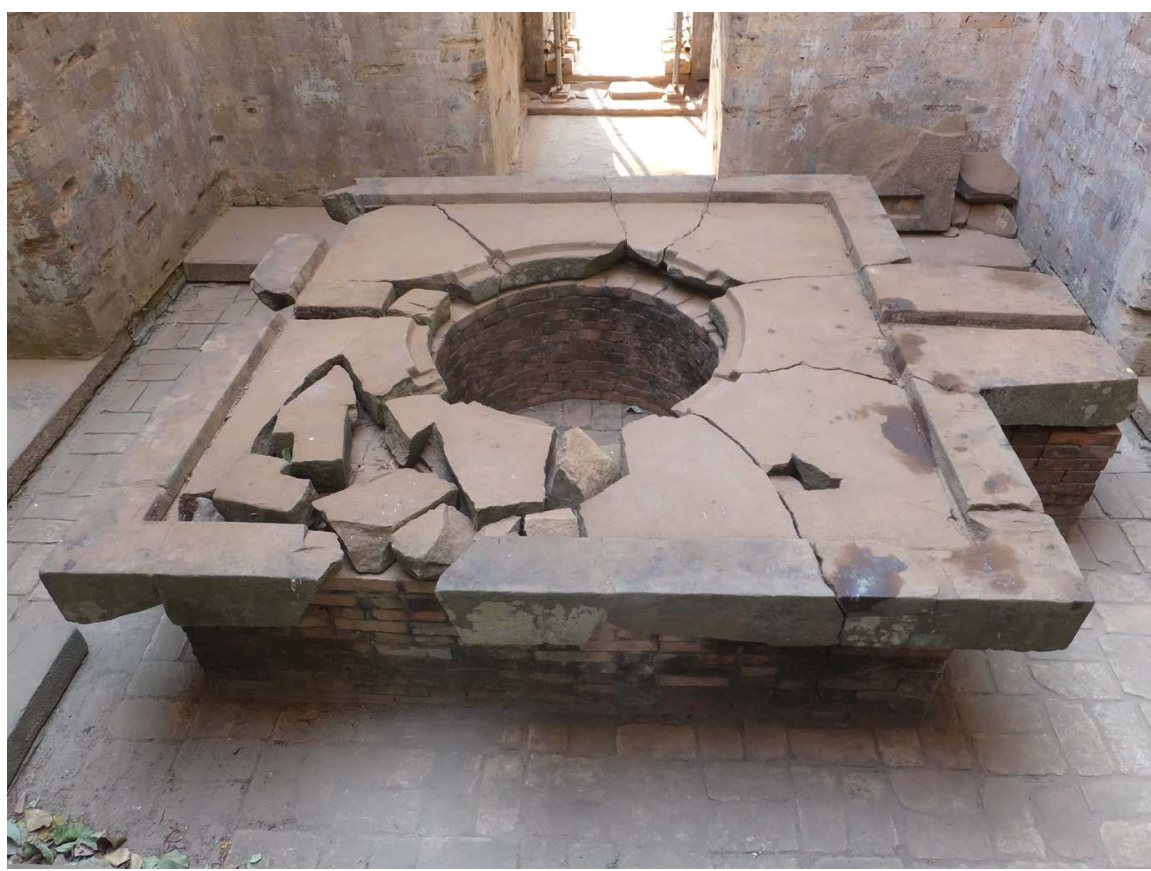

Figure 6. Reassembled pedestal in the chamber of central shrine (N1) of Prasat Sambor. 


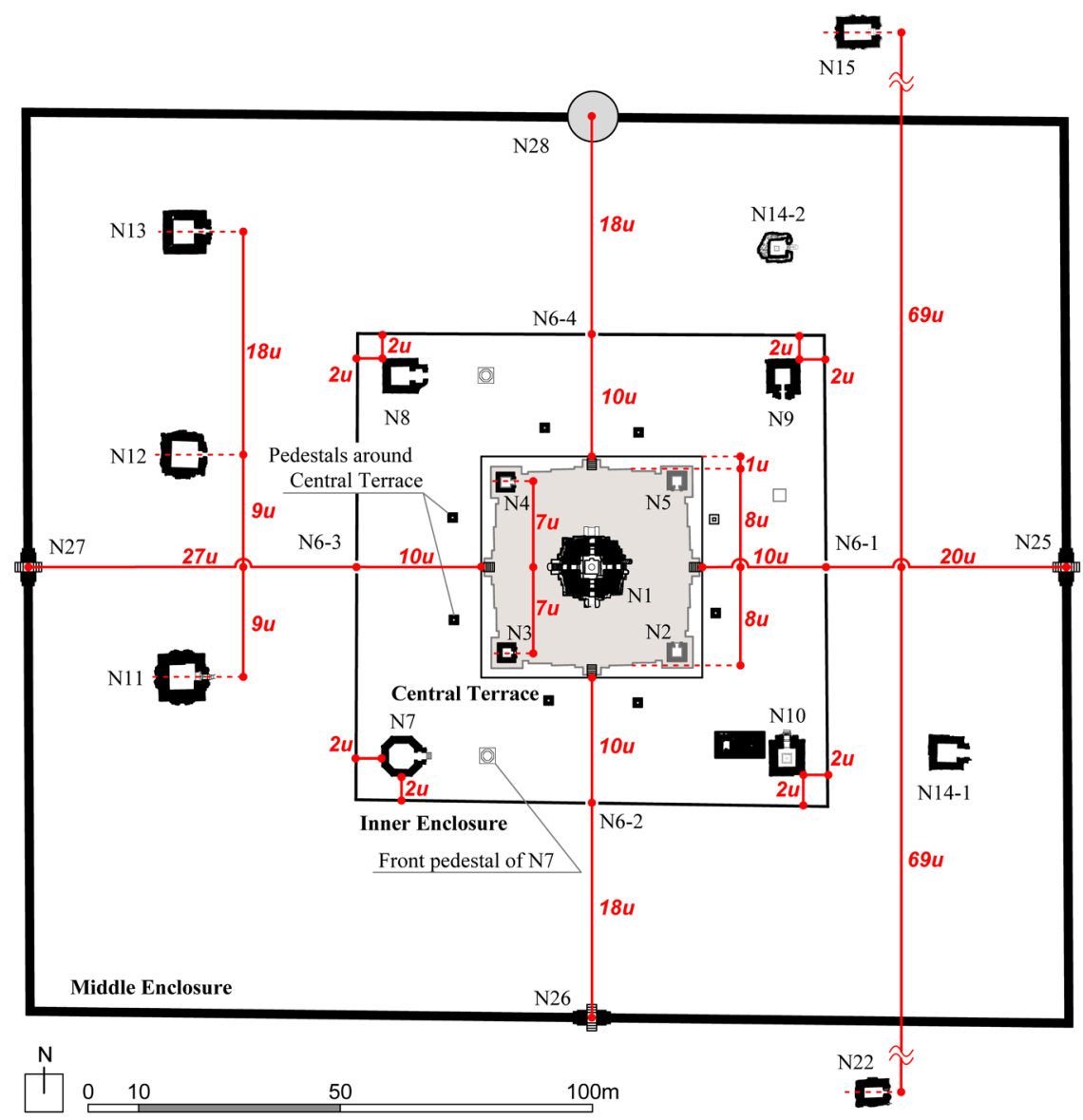

Figure 7. Plan of Prasat Sambor within middle enclosure with dimensions in each part (1 $\mathrm{u}=6$ hasta $=2439 \mathrm{~mm}$ )

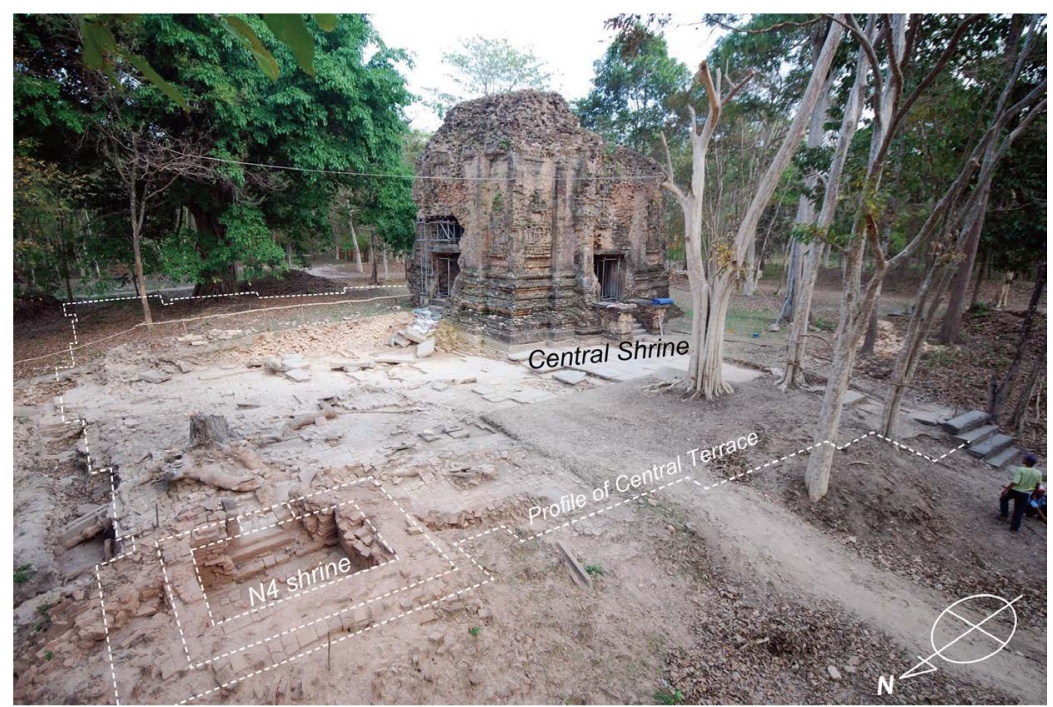

Figure 8. Central shrine (N1) and northwest corner shrine (N4) on the central terrace of Prasat Sambor during the archaeological excavation survey (view from northwest).

components. These shrines would have been dedicated to the eight murti (embodiments) of Shiva in the form of the sun, moon, fire, earth, water, wind, and 
ether, and the king himself (Coedès, 1965). The eight pedestals distributed around the central terrace of Prasat Sambor closely resemble this early-Angkorian configuration and arguably represent the first known example of these components.

The central terrace stands in the center of the inner enclosure. The inner enclosure forms a square demarcated by four walls. At the center of each side, gateways were constructed and worshippers could access from every sides. An archeological survey around the center of the eastern side revealed that the opening is $2.8 \mathrm{~m}$ wide (Figure 9). However, no traces of any gopura (monumental gateway) were found. This entranceway is typically rather basic; an entrance with sandstone side posts. In the inner enclosure, a brick pavement $1 \mathrm{~m}$ in width was excavated. The paving likely formed part of a walkway running along the inner enclosure perimeter (Shimoda et al., 2006). It is possibly to consider this walkway structure as the origin of the gallery which was a common component of the temple complexes in the Angkorian period.

Shrines N7 to N10 are located at the four corners within the inner enclosure. Of these, the eastern two shrines, N9 and N10, face each other. Shrines N9 would have contain a statue of Durga, while Shrine N10 would have contains a statue of Harihara. An archeological survey on the western side of N10 uncovered a brick structure which has two chambers. The main chamber had a pillared open-air structure. A fragmented statue of Ganesh was found in a pit in the center of this chamber (Shimoda \& Shimamoto, 2012). This structure may constitute the first example of a "Library" (a name given by French scholars for a specific-type of building; usage unknown) which was typically constructed in Angkorian temples. The western shrines, N8 and N7, face to the east. In front of these shrines lie large stone pedestals. A statue of Vajimukha (a deity also known as Kalkin), of a 10th century style, was found in the N7 shrine. Due to the style

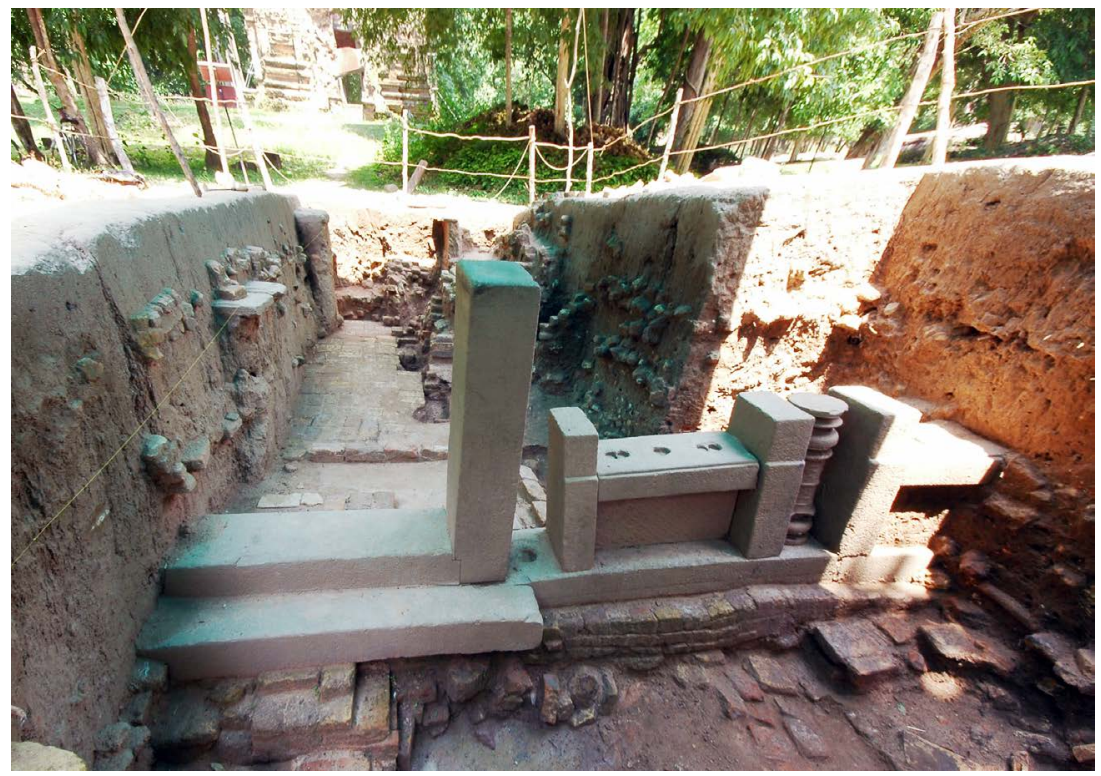

Figure 9. Excavated gateway (N6-1) at the center of eastern side of the inner enclosure (gateway was excavated only north half of the structure). 
of this statue, this statue would have replaced the original deity statue. It is unclear what statue would have stood on the pedestal in front of the shrines N7 and N8, but it is hypothesized that it was the Vahana (mount) of the deity to whom both shrines were dedicated. Currently, a set of octagonal shaped pedestal was reconstructed in front of the shrine N7 (Figure 10). All the deities enshrined in the inner enclosure are closely related to Shiva. This configuration mirrors the cosmological layout depicted in a mandala in which the main deity Shiva appears in the center of cosmological grid.

The middle enclosure forms a rectangle; its east-west sides are slightly longer than those of the north-south sides. The west space between inner and middle is larger than east space, and three brick shrines (N11, N12 and N13) are located within this larger space. Two smaller shrines stand in this enclosure, one in the eastern space (N14-1) and the other in the northern space (N14-2). Gateway structures, gopura, were located on each sides of the middle enclosure. These structures were exactly located on the axis lines from the central shrine. Through the archaeological excavation survey, two floor levels were identified at $80 \mathrm{~cm}$ and $2 \mathrm{~m}$ below the present ground level nearby the eastern gopura. The evidence of these earlier paving indicates that the present gopura was a reconstructed structure in a later period (Shimoda et al., 2006). This finding implies that the level of the outer area from inner enclosure was originally lower than the present level, and the temple complex was formed like a stepped pyramid even though the height of these steps is limited.

As mentioned earlier, the outer enclosure has been poorly preserved, and only a few parts remain above ground level. On the western side, a part of the gopura is still preserved where the wall intersects the main axis. It is likely that the north and south gopuras were also constructed because mounds of the structures were

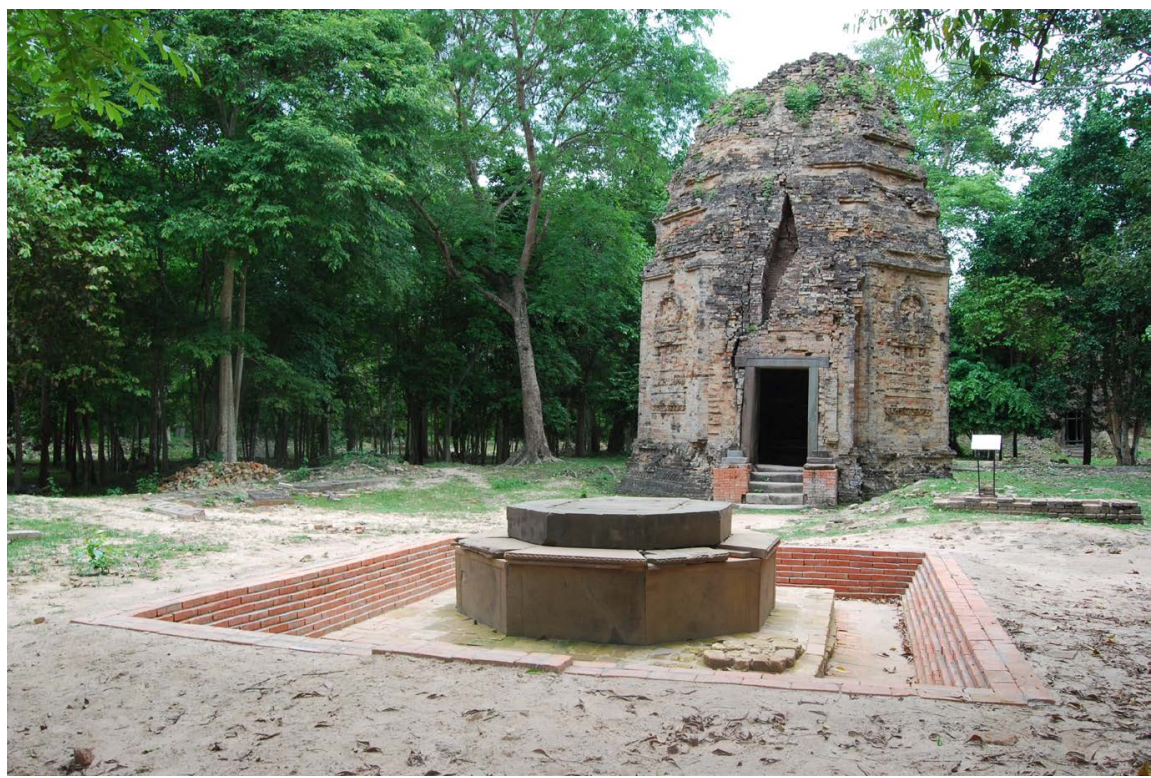

Figure 10. Southwest shrine (N7) and a reconstructed front pedestal in the inner enclosure of Prasat Sambor. 
confirmed on the northern and southern sides of this enclosure where the walls intersected the north-south axis. Regarding the eastern side, an archeological survey revealed the remains of a sandstone stepped terrace. The earthen causeway structure stretches eastward and is $1.9 \mathrm{~km}$ long from this terrace.

The western and northern space between the outer and middle enclosures are relatively larger than the eastern and southern space. Five shrines were identified in the northern space. Of these, N15, N16-1, and N16-2 are situated adjacent and parallel, forming an architectural triad. The middle shrine in this triad, N15, is exactly in symmetrical position to N22 relative to the main axis of this complex. A statue of Brahma was found near N22, and is proposed to be the original enshrined deity of this shrine because the pedestal found in this shrine fits this statue. It is unclear what deity was enshrined in N15, but it may well have been Vishnu, which would mean that the temple complex housed all three members of the Trimurti, the triple deity in Hinduism. Based on this hypothesis, Vishnu was enshrined in the north shrine N15, Shiva and his attendants were enshrined in the shrines at central part of the complex, and Brahma was enshrined in the south shrine N22. Such a configuration emerges later in Angkorian temples. For example, Phnom Bok which was founded in AD 910 is a realization of the configuration of the Trimurti by architectural triad. Three main shrines were dedicated to each of the three members of the Trimurti. If the above hypothesis in Sambor Prei Kuk is correct, then it would mean that this Hinduism configuration was already manifested in a temple complex in the pre-Angkorian period.

\subsection{Composition of the Prasat Yeai Poeun}

Prasat Yeai Poeun has two enclosures with several shrines within (Figure 11). The outer closure measures approximately $258 \mathrm{~m}$ along the east-west axis and $244 \mathrm{~m}$ along the north-south axis. An inscription found in the temple complex bears the name of Isanavarman I, who likely ordered the construction of this temple in the early 7th century the same as Prasat Sambor. The central shrine (S1) is the largest structure in this group of monuments and measured $22 \mathrm{~m}$ high. A severely damaged large pedestal has been reconstructed inside the shrine. An inscription on this pedestal indicates that the shrine was dedicated to "Smiling Shiva." Each component in this temple complex is described below, starting from the center outward.

The central shrine forms a rectangle oriented lengthways along the east-west axis. It has only one entrance, on its eastern side. This shrine stands on a terrace with staircases in the four cardinal point sides. However, it functions more as the base of a shrine rather than forming a spacious upper level like the central terrace of Prasat Sambor (Figure 12).

The inner enclosure forms a square. All four sides of the enclosure have a gopura. The gopura on the northern and southern side s (the lateral gopura) are located slightly west from the midpoint. The outer door opening of these lateral gopura were closed by brickwork, making them impassable for access into the 


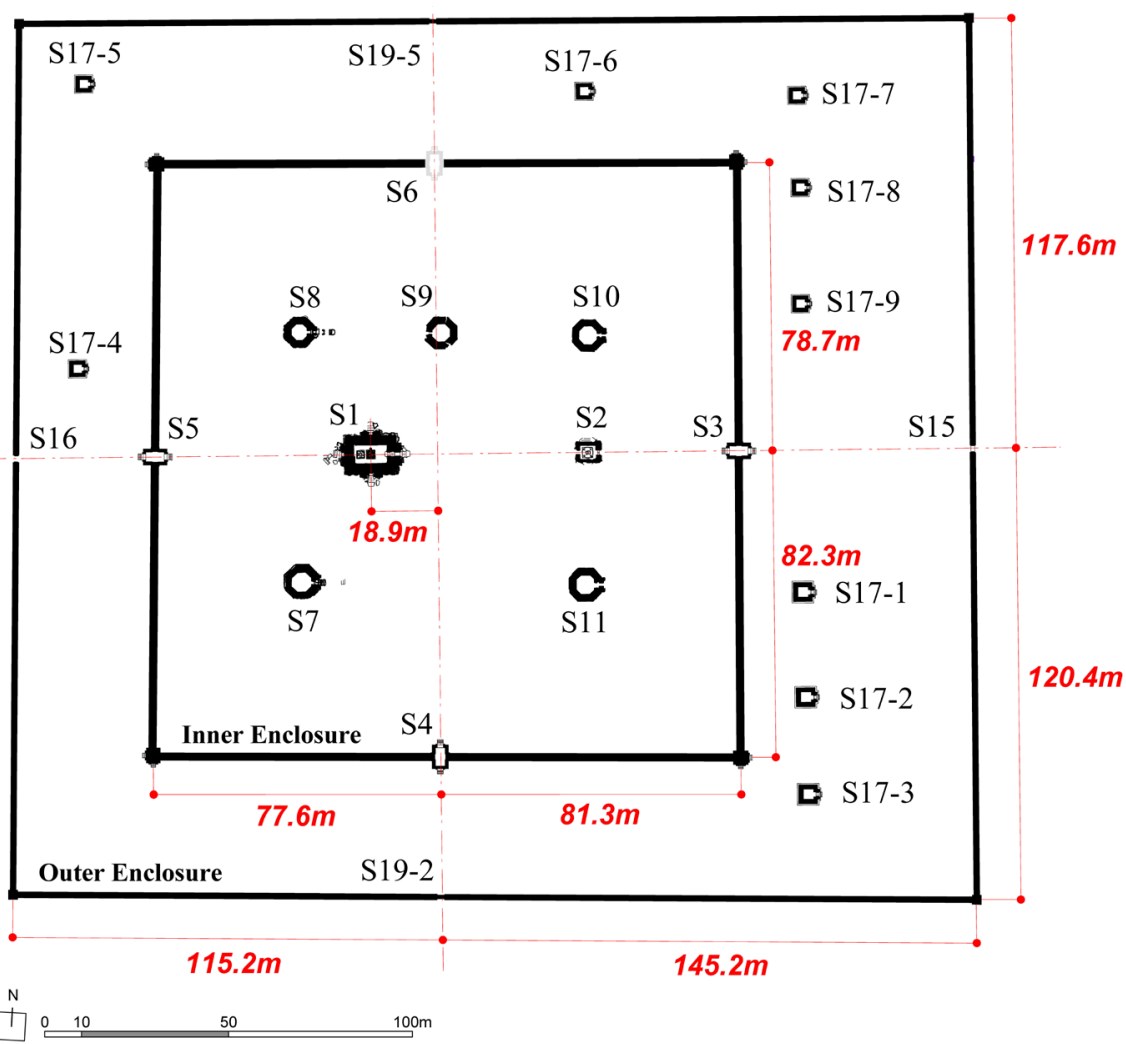

Figure 11. Plan of Prasat Yeai Poeun with dimensions showing asymmetrical composition.

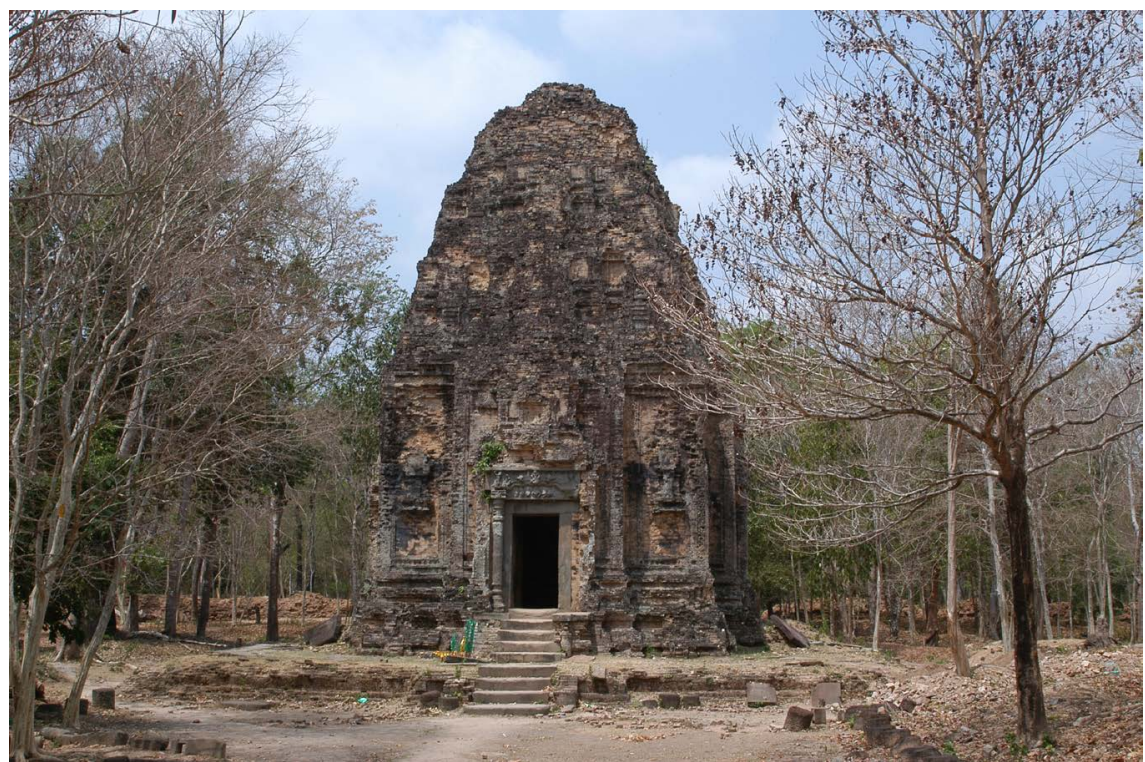

Figure 12. Central shrine (S1) of Prasat Yeai Poeun (view from east).

enclosure (Figure 13). This false door would be originally closed because the brickwork in the door frame is well constructed same as other initial brick structures. A series of circular bas-relief decorative elements, medallions, $107 \mathrm{~cm}$ in diameter adorned both sides of this inner enclosure. Each medallion seems to 


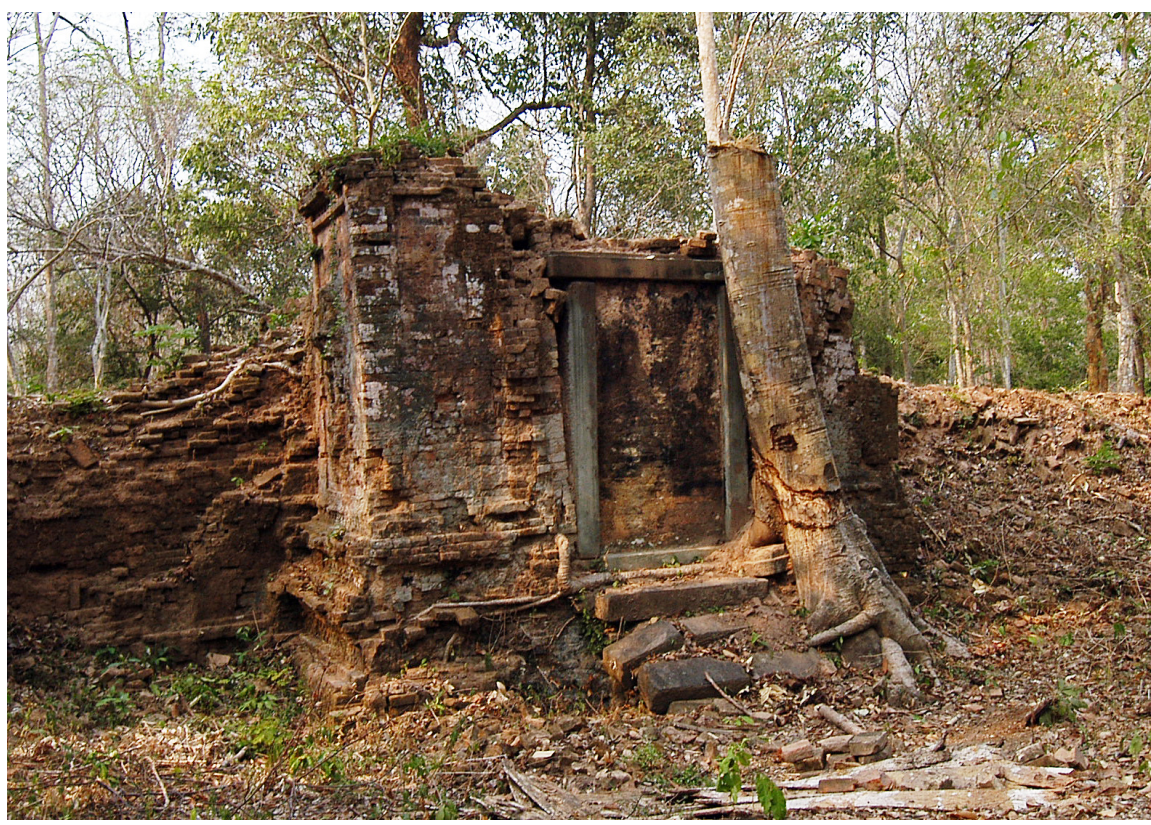

Figure 13. Closed door opening of the south face of south gate (S4) in Prasat Yeai Poeun (view from south).

depict a different mythical scene, but most are incomplete and the story of these mythical scene has been unrevealed. Much of the wall lies buried beneath a mass of fallen bricks, and further surveys may uncover more panels of medallions. No examples can be found in later periods of a wall being adorned by decorative medallion curving. However, in the late of the Angkorian period, some temple complexes were depicting mythical epics on the walls of galleries, and the medallions in Prasat Yeai Poeun can be identified as a forerunner of this practice.

The central shrine (S1) is aligned with the east and west gopura, but it is positioned slightly west of the lateral gopuras, creating a larger space in front of the shrine. In this front space, a structure called a mandapa (shrine S2) is positioned (Figure 14). This structure contains a decorative pedestal which consists of a platform and roof element supported by four pillars. An inscription on the stone plate on the platform indicates that this structure was dedicated to Nandin the bull, who was Shiva's vahana. In the Angkorian period, the adjunctive praying chamber was adjoined directly in front of main chamber, but in this case the front chamber was separately constructed in the front space. Lines of laterite columns were excavated in a past excavation survey, and a walkway may have connected these two structures.

Besides the mandapa, there are five octagonal shrines (S7 - S10) that still stand in the inner enclosure. In addition, a past archaeological excavation survey uncovered a base of the square structure in front of the entrance to S7 (Goloubew, 1927). Four of the five octagonal shrines are arranged symmetrically. The fifth shrine, $\mathrm{S}$, is asymmetrical with the others, and its entrance faces west while the others all face east. The layout of this shrine represents a distinctive feature of Prasat Yeai Poeun; no analogous examples appear in later temples. Shrine S9 


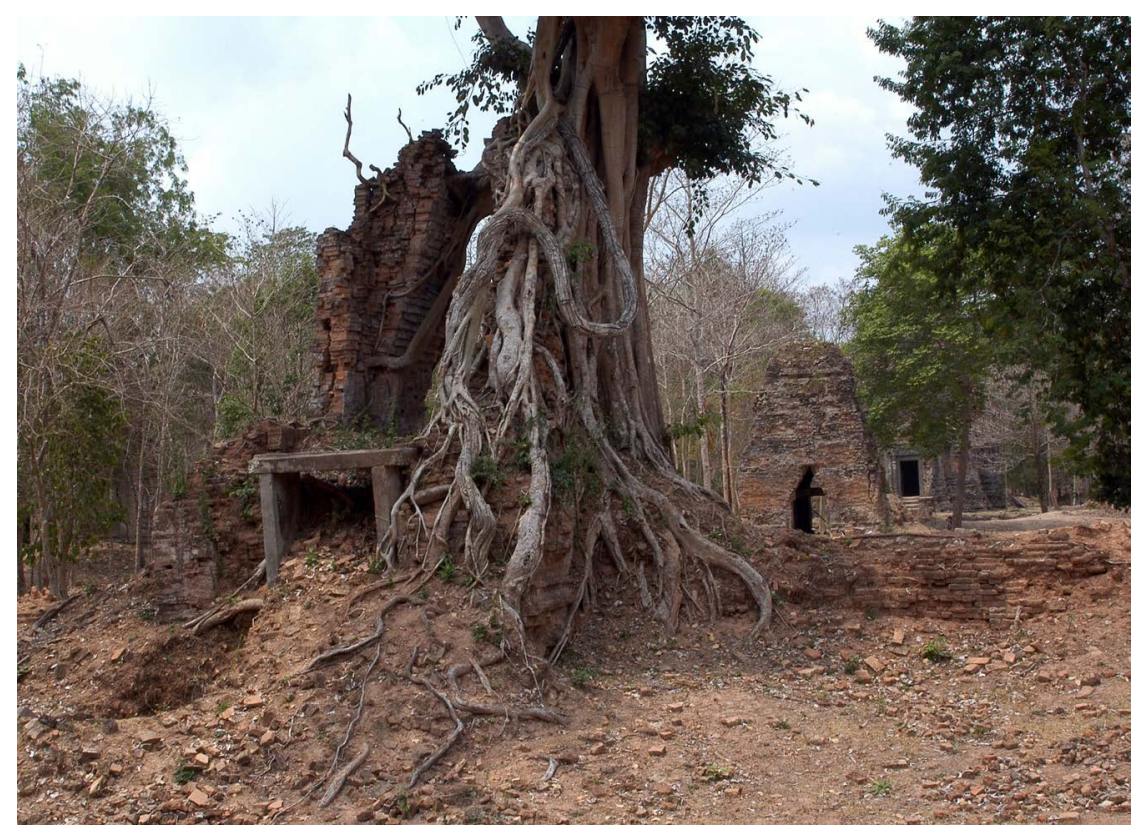

Figure 14. Alignment of three structures on the main axis line in Prasat Yeai Poeun; east gate of the inner enclosure (S3), mandapa (S2), and central shrine (S1).

stands on the north-south axis line, such that anyone standing at the point where the east-west main axis and north-south vertical axes intersect would find their northerly line of sight obstructed. Thus, whereas Prasat Sambor has a design that clearly radiates out from the center evenly in square-wise fashion, Prasat Yeai Poeun extends only lengthways and restricts the width way line of sight and travel, thus emphasizing frontal perspective and depth.

The outer enclosure is made of laterite, and is slightly rectangular along the major axis. All four gopuras on all sides are in a poor state of conservation, but it is obvious that both doors of the east and west gopura are open and door of north gopura was closed. Although the south gopura was severely damaged, the door would be closed the same as the north gopura. Thus, the door of north and south gopura might be closed the same as the gopura in the inner enclosure. Remnants of an earthen causeway appear intermittently along a $2.6 \mathrm{~km}$ stretch leading out from the eastern gopura. Nine shrines are distributed between inner and outer enclosures. Those in the southeast corner (S17-1, S17-2, and S17-3) are brick structures while the rest are made of laterite. The architects probably intended to build an equal number of shrines on each side by brick but were forced to modify and abandon the plan during construction.

\subsection{Composition of Prasat Tao}

Prasat Tao has an inner and outer enclosure (Figure 15). The outer enclosure measures $283 \mathrm{~m}$ along the east-west axis and $274 \mathrm{~m}$ along the north-south axis. With exception of the central shrine (C1), which stands $22 \mathrm{~m}$ high, all components within this complex are severely damaged and thick layer of sedimentary soil is covered entire precinct area. This situation, coupled with the lack of prior 


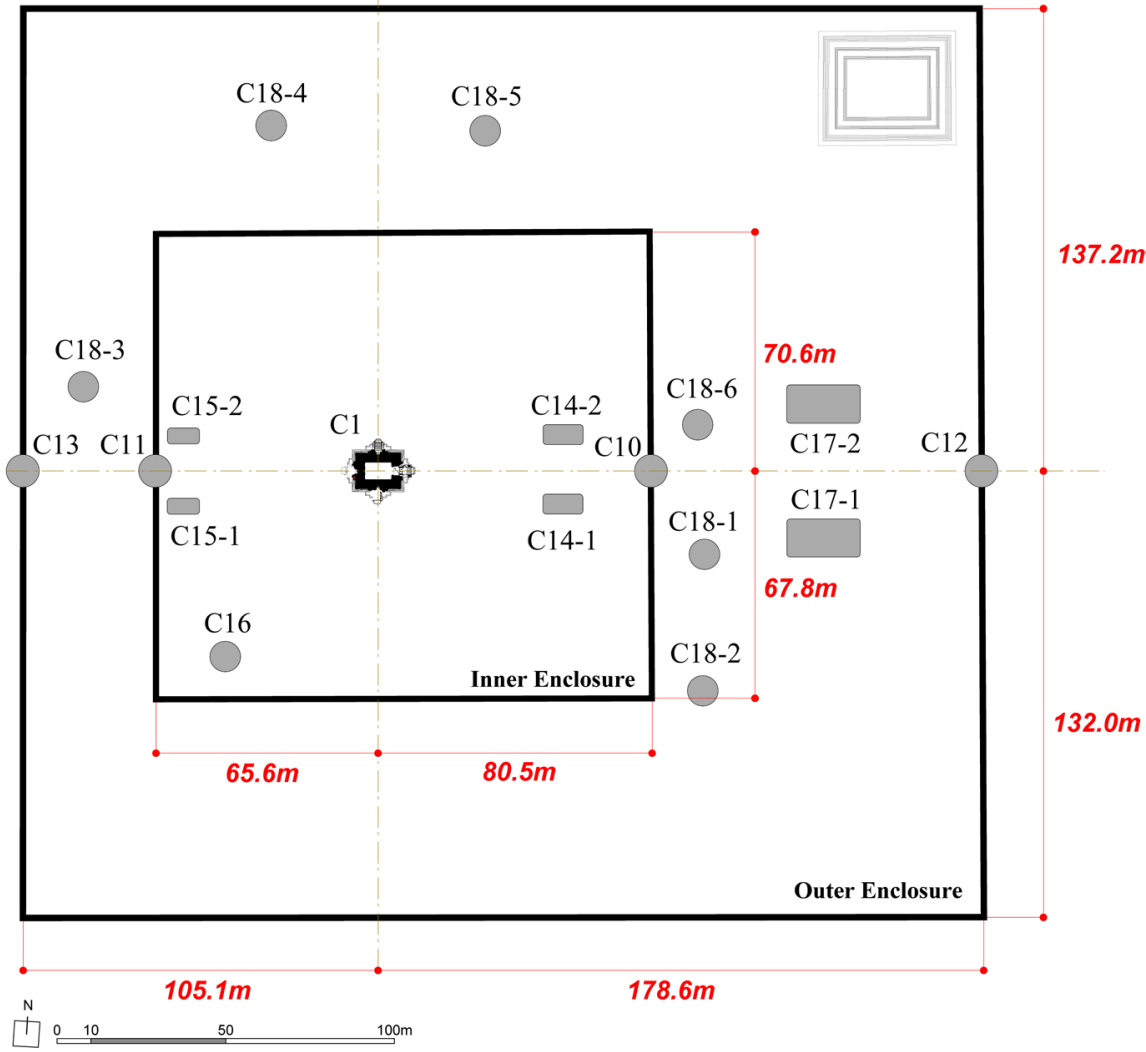

Figure 15. Plan of Prasat Tao with dimensions showing asymmetrical composition.

archeological surveys, limits what is known about the composition of this temple complex.

The central shrine is rectangular and has a front door opening (Figure 16). The door opening is adorned with a decorative lintel and colonnette that have been well preserved. These decorative elements are classified to the Kompong Preah style, which is attributed to a relatively late stage of the pre-Angkorian period. Carved lion figures adorn the sides of three of the four stairways.

The inner enclosure forms a rectangle oriented lengthways along the major axis. There are two gopuras on the east and west sides. The central shrine is positioned slightly westward of the enclosure center the same as Prasat Yeai Poeun. Apart from the central shrine, five other structures were constructed in the inner enclosure. The layout of these structures differs from that in Prasat Sambor and Prasat Yeai Poeun where the shrines are arranged in the four corners.

The outer enclosure, likewise, is rectangular, with the long side to the east and west and with gopura only on the eastern and western sides. The walls are made of laterite, but the gopura are brick constructions. Remnants of eight structures appear in this enclosure. Four are symmetrical with a horizontal axis while the other four have an irregular layout. Lacking any lateral gopura, Prasat Tao has a longitudinal composition that emphasizes depth to an even greater extent than does Prasat Yeai Poeun.

The straight causeway would be extended from the east gate of the outer 


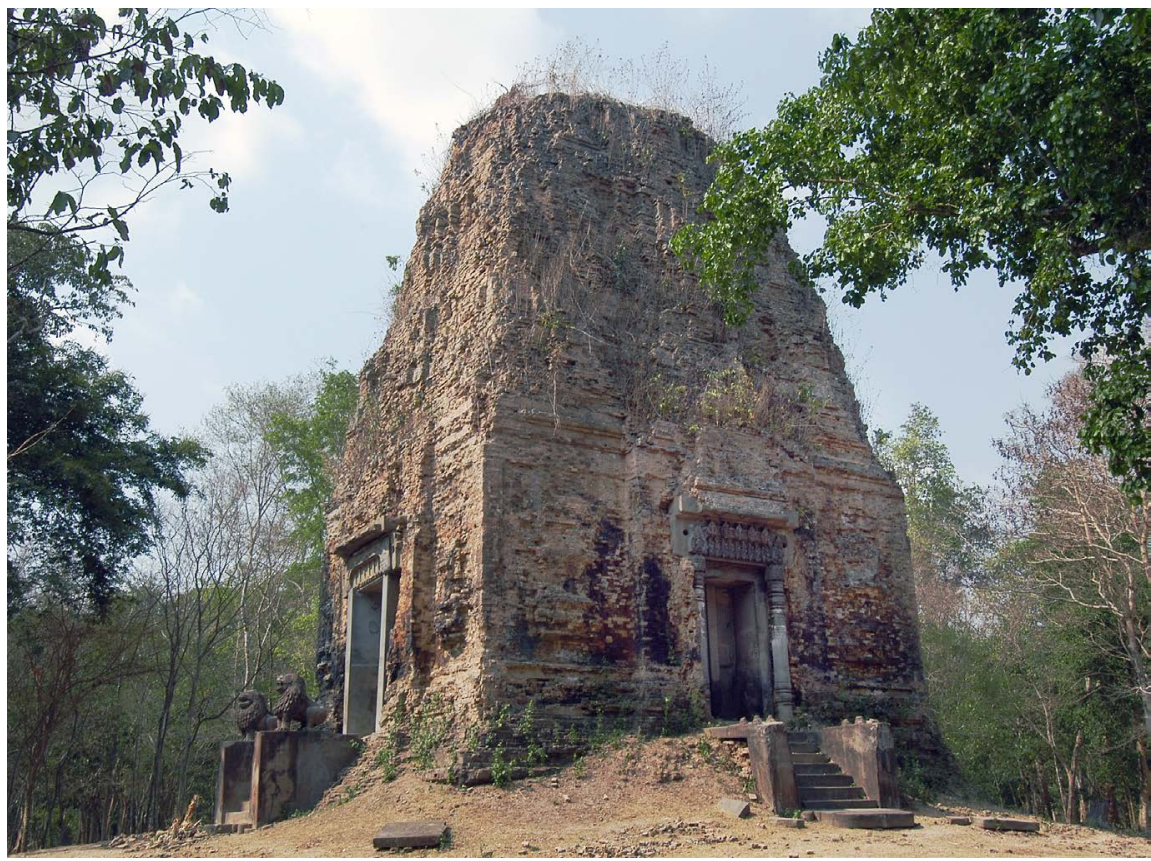

Figure 16. Central shrine (C1) of Prasat Tao (view from northeast); front door is opened and accessible to the chamber but other three sides are only decorated with false doors and steps.

enclosure, the same as Prasat Sambor and Prasat Yeai Poeun, but only limited earthen evidence is observed today. Many artifacts were excavated in the previous excavation surveys along this causeway $200 \mathrm{~m}$ east from the outer enclosure (Groslier, 1981, Shimamoto et al., 2008, Kubo et al., 2012). It was estimated that the front space of this temple was occupied by some form of wooden facilities supporting the religious activities of the temples around here.

To the west of the outer enclosure lies a group of shrines (M32 - M36) (Figure 3). It is unclear whether these shrines formed an integral part of the temple complex. However, it is worth noting that Prasat Sambor has three shrines toward the rear space in the middle enclosure. Likewise, the shrines west of Prasat Tao, though situated outside of the enclosure, may have served as satellite shrines to this temple complex.

\subsection{The Three Temple Complexes: Prototypes of Two Architectural Lineages}

The three temple complexes described above all have multiple enclosures and several shrines, but each complex has its own distinctive layout. Fundamentally, however, whereas the layout in Prasat Yeai Poeun and Prasat Tao are not so dissimilar, the Prasat Sambor layout is markedly different from the other two. This layout is distinctive in three respects:

1) The Prasat Sambor central shrine is square with door openings on all four sides while the central shrine of the other two complexes are rectangular and have single door opening on the front side. 
2) The Prasat Sambor central shrine is situated in the center of the inner enclosure, while the central shrines of the other two complexes are positioned rearward of the inner enclosure.

3) In Prasat Sambor, lateral gopuras are aligned with the central shrine, while in the other two complexes the lateral walls either have a gopura that are not aligned in this way or have no lateral gopura at all.

These distinctive features possible reflected the different designing concepts for these temples; Prasat Sambor has a layout that radiates outward evenly in all four directions from the central shrine, by contrast, the layout of the other two complexes extends along one axis, emphasizing the frontal line of sight. Differences in religious significance and their alignment should also be considered.

These two layouts would be the prototypes of two architectural lineages delineating the numerous temples built in the Angkorian period (Figure 17). Prasat Sambor pioneered the pyramidal design that characterized the state-temple. As mentioned in the introduction, the more powerful rulers only constructed pyramidal shaped state-temples (Figure 18). After the initial state-temple of Prasat Sambor, subsequent kings constructed the following pyramidal state-temples as follows: Ak Yum (8th century), Rong Chen (early 9th century), Prasat Bakong

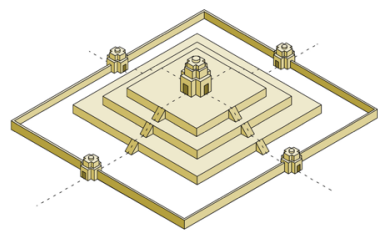

Type A

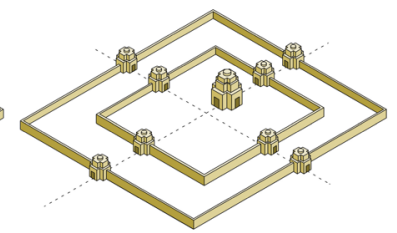

Type B1

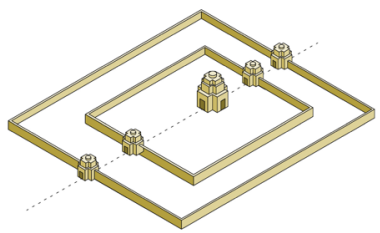

Type B2

Figure 17. Diagram of major three compositions of Khmer temple complex; (A) Type of pyramidal state-temple derived from Prasat Sambor, (B1) Type of flat complex derived from Prasat Yeai Poeun, (B2) Type of flat complex derived from Prasat Tao.

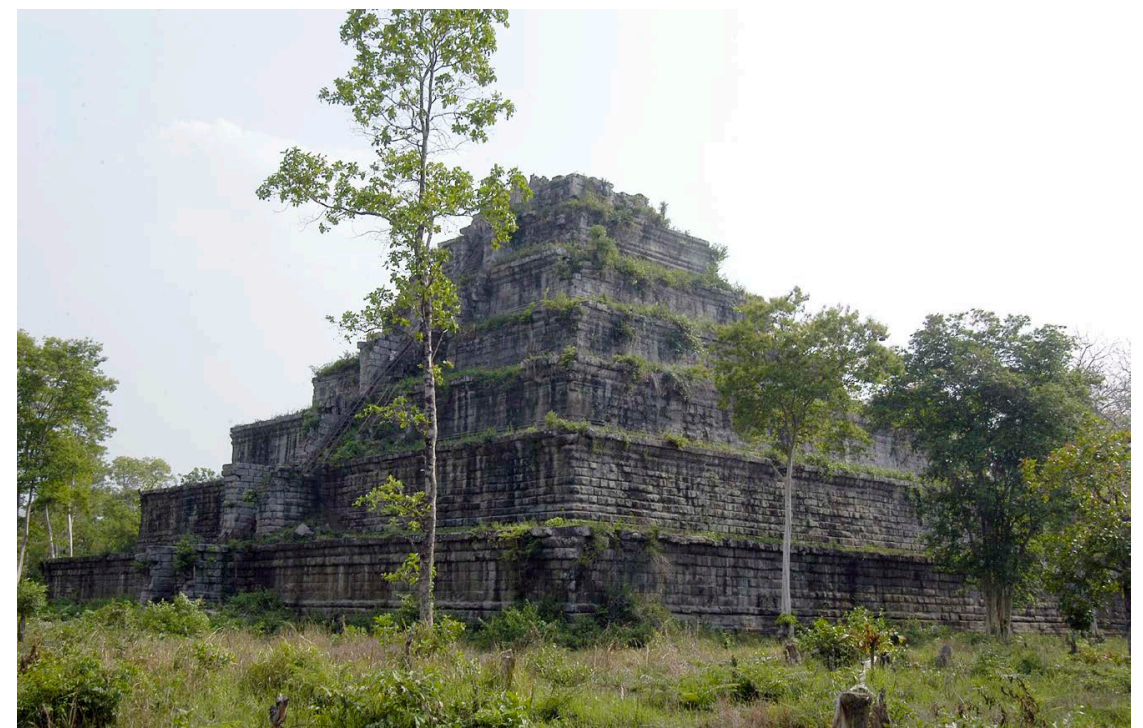

Figure 18. Pyramidal structure (Prasat Prang) in the Prasat Thom (view from northeast); steep staircase was constructed only front face and other three sides are not accessible. 
(881), Phnom Bakheng (900), Prasat Thom (928), East Mebon (952), Pre Rup (961), Ta Keo (c. 1000), Phimeanakas (late 10th to early 11th century), Baphuon (c. 1060), Angkor Wat (1113-c. 1150), and Bayon (late 12th century to early 13th century).

These temples have a stepped tiers elevation, and central shrines which enshrined the deity statue associating the king and deity were constructed at the uppermost level of these mountain temples. These central shrine opens on all four sides with a square plan, and the prestige of the nation god would be equally extended radially. With exception of Prasat Thom, staircases and gopura are positioned along the horizontal and vertical axes extending from the central shrine, creating unbroken lines of travel in the cardinal directions.

Regarding the exception noted above, it is debatable that Prasat Thom should be classified as a state-temple. This pyramidal temple was built in Chok Gargyar (now known as Koh Ker), was briefly the capital in the early 10th century. The temple complex of Prasat Thom is divided into western and eastern sections. The western section, known as Prasat Prang, consists of a tall pyramidal structure (Figure 18). The eastern section has a cluster of shrines and other structures on flatland within a walled and moated enclosure. Both sections have a shrine at the center, but neither has openings on all four sides. In addition, neither section has straight routes to a shrine at the center from four sides. However, it has been decided to nonetheless classify this complex as a state-temple based on the work of Codès (1965): Coedès argued that Prasat Thom played a crucial role in the development of the pyramidal temple in that it pioneered the idea of having a highly symbolic pyramid that was separate from the other compositions in the complex. Another reason for treating Prasat Thom as a state-temple is this complex obviously served as the most significant temple in the relocated capital Chok Gargyar in the 10th century.

Besides the temples shown in Figure 19, Prasat Chaom Sram, located in Preah Vihear Province, is also a pyramidal temple complex (Figure 20). Although this temple is not as familiar to researchers as other temples, the composition of this temple is strikingly comparable to Pre Rup and East Mabon. However, this temple stands apart from the other examples in that it lacks a key feature of pyramidal state-temples as it has no lateral gopura. Additionally, unlike all other state-temples, it is located some distance away from a political center of the kingdom. Therefore, this pyramidal temple is not classified as a state-temple, on the other hand, it was possibly an important regional temple.

As for the other architectural lineage, as exemplified in its prototype, Prasat Yeai Poeun, this temple was composed by several structures on flat ground and layout emphasizes frontal perspective and depth of precinct. The central shrine is rectangular and it is positioned slightly rearward in the space of the enclosure. This architectural lineage in the early-Angkorian period is further divided into two subcategories. Regarding the first subcategory, as in Prasat Yeai Poeun, lateral gopura are positioned roughly at the midpoint of the line such that they are 


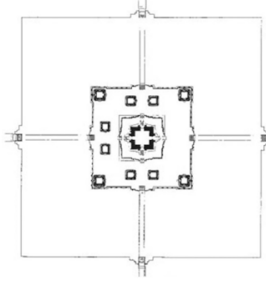

Ak Yum

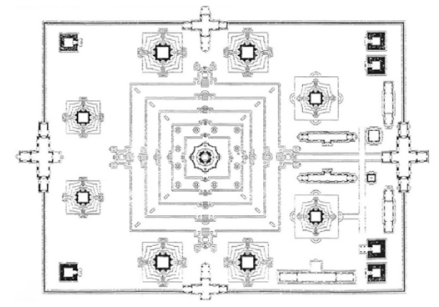

Bakong

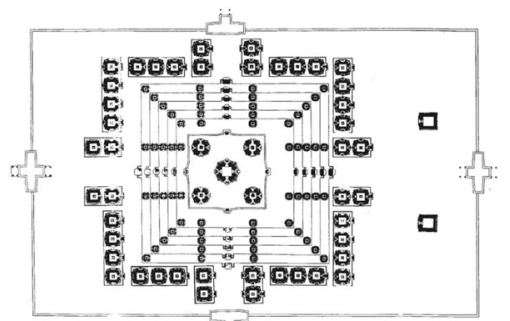

Phnom Bakheng

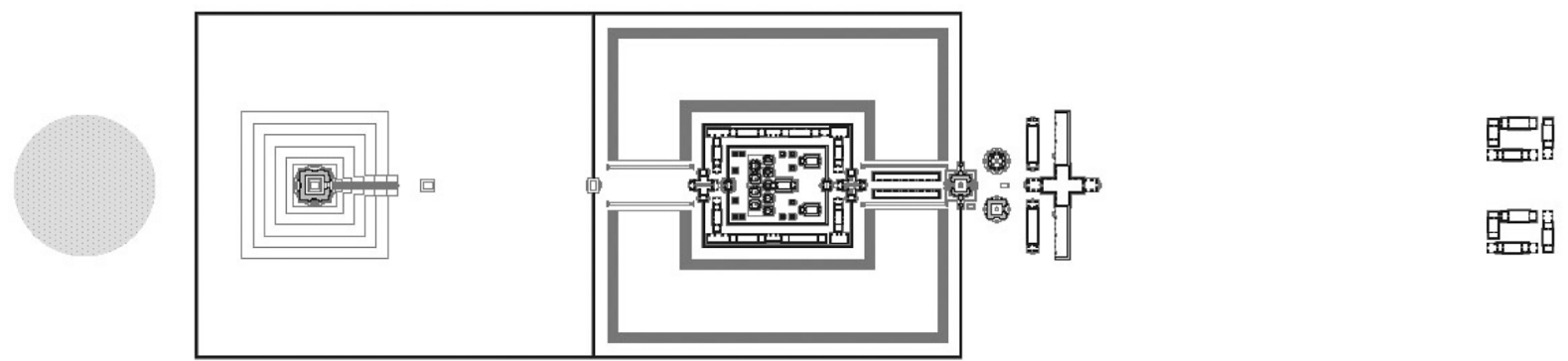

Prasat Thom

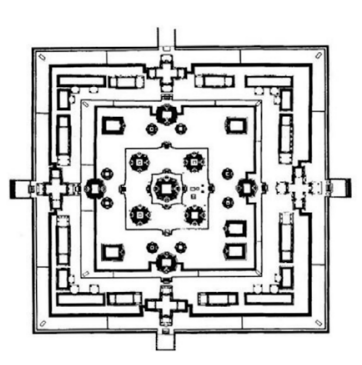

East Mebon

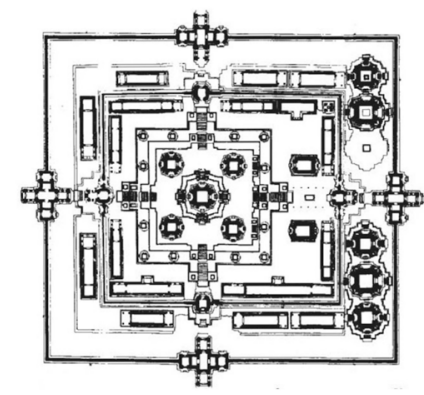

Pre Rup

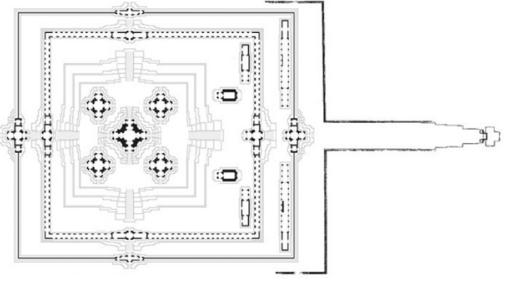

Ta Keo

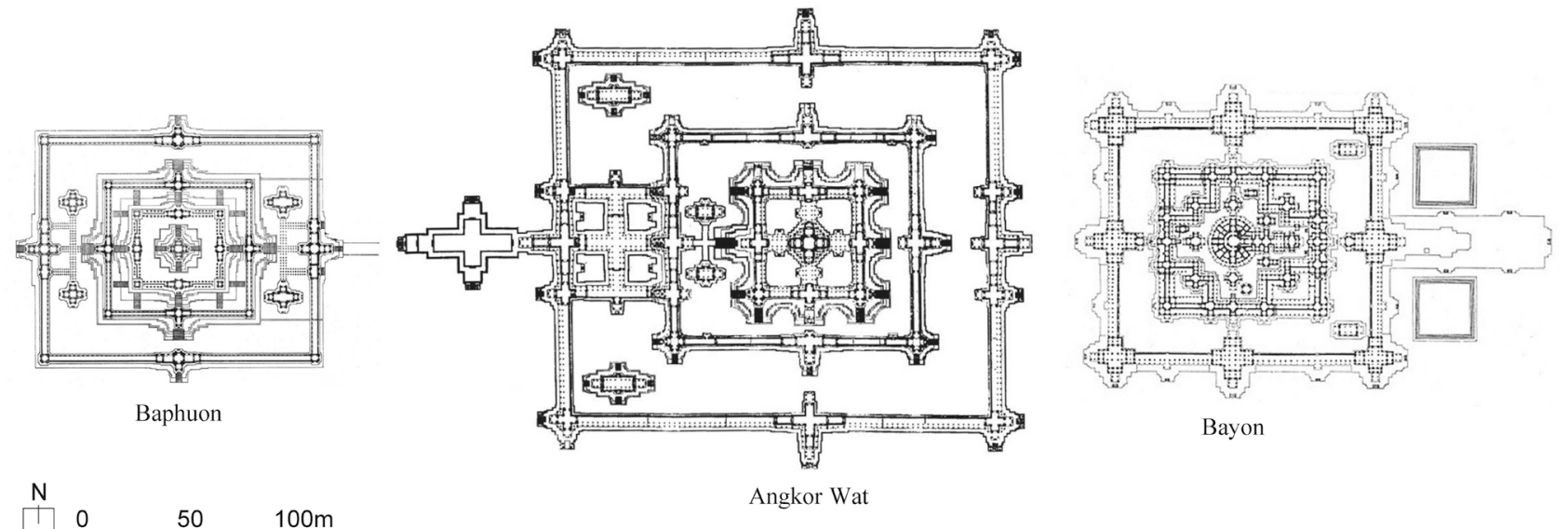

Figure 19. Plans of the pyramidal state-temple in Angkorian period (source: École française d'Extrême-Orient).

out of alignment with the central shrine. Strictly speaking, the lateral gopura of Prasat Yeai Poeun is slightly rearward from the midpoint of the wall; the both gopuras are positioned about $1.5 \mathrm{~m}$ rearward from the midpoint of the longitudinal wall that is about $159 \mathrm{~m}$ long, such that it lies $81.3 \mathrm{~m}$ from the eastern end the wall and $77.6 \mathrm{~m}$ from the western end. In the second subcategory, there are 


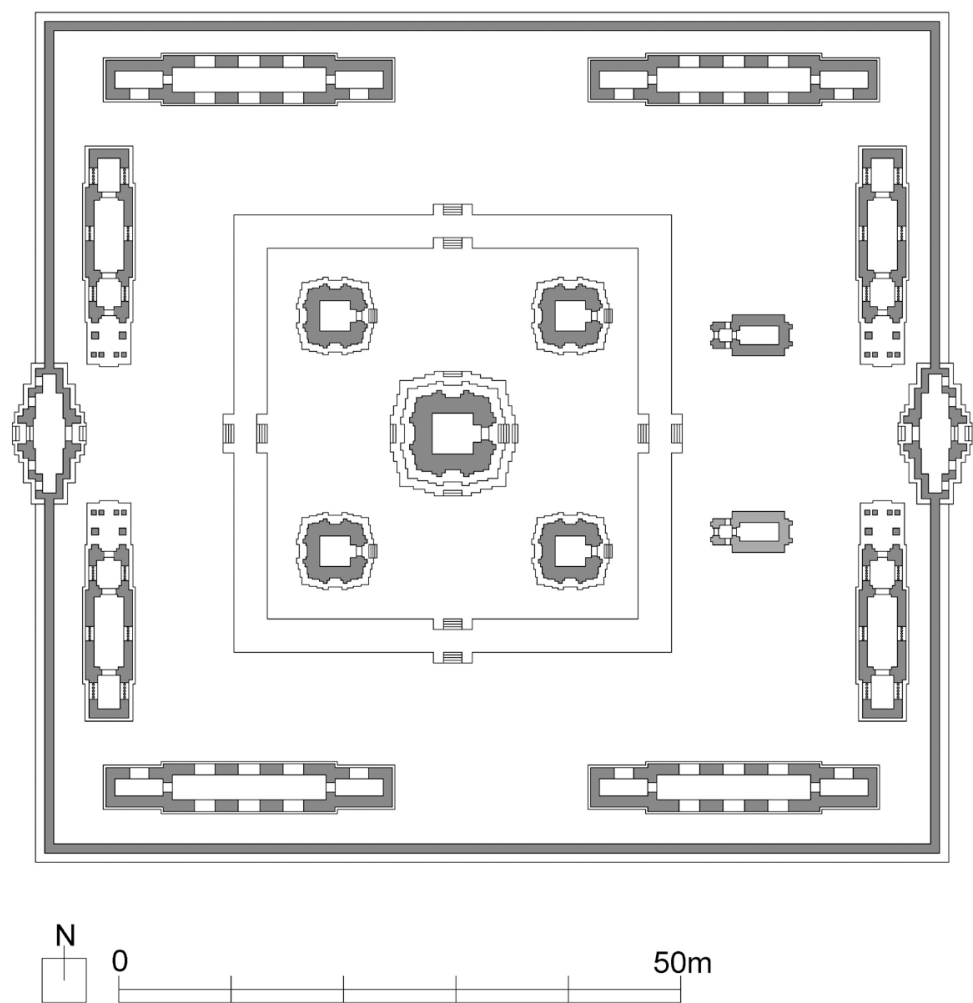

Figure 20. Plan of Prasat Chaom Sram (central part of the complex).

no lateral gopura, as is the case with Prasat Tao. An example of the first subcategory, Prasat Yeai Poeun style, in early-Angkorian period is Phnom Krom (9th century) (Figure 21), and an example of the second category, Prasat Tao style is Preah Ko (879) (Figure 22).

From the middle of the Angkorian period onward, this lengthways layout blended with the pyramidal temple resulting in a new style of temple complex. This new style retained some features of the lengthways layout; the central shrine is a rectangular plan with an antechamber positioned at the rear space in the enclosure. However, it combined these features with the pyramidal temple; the central shrine has door opening on all four sides and is aligned with the lateral gopura. While remaining clearly distinct from the pyramidal state-temple in that the overall temple complex has a flat layout rather than having elevated stepped tiers structure, this style manages to fuse two theretofore separate lineages of temple design. Examples of this hybrid genre include the Bayonesque temples of Ta Prohm, Preah Khan, and Banteay Kdei. These temples mark a shift to a larger, more intricate temple design; one that required as many personnel and monetary resources as were required for a state-temple construction.

\subsection{Asymmetric Composition of the Three Temple Complexes}

In the earlier descriptions of the three temple complexes, it was briefly noted that the central shrine is positioned in the center or slightly to the rear of the center of the inner enclosure. However, the result of detailed survey reveal that 


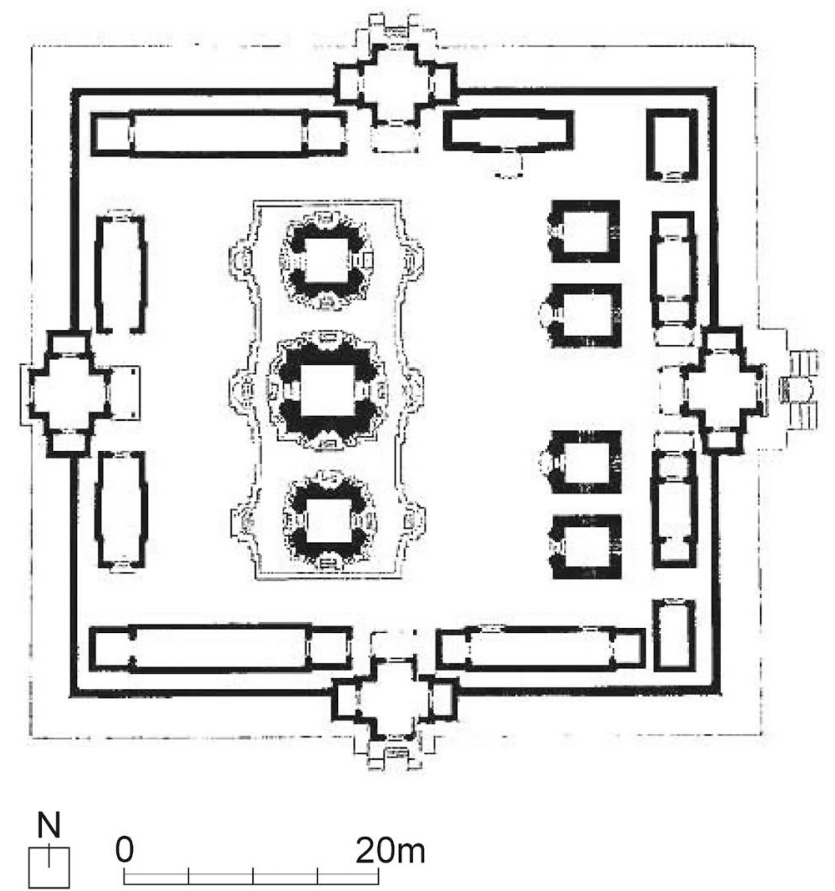

Figure 21. Plan of Phnom Krom (source: École française d'Extrême-Orient).

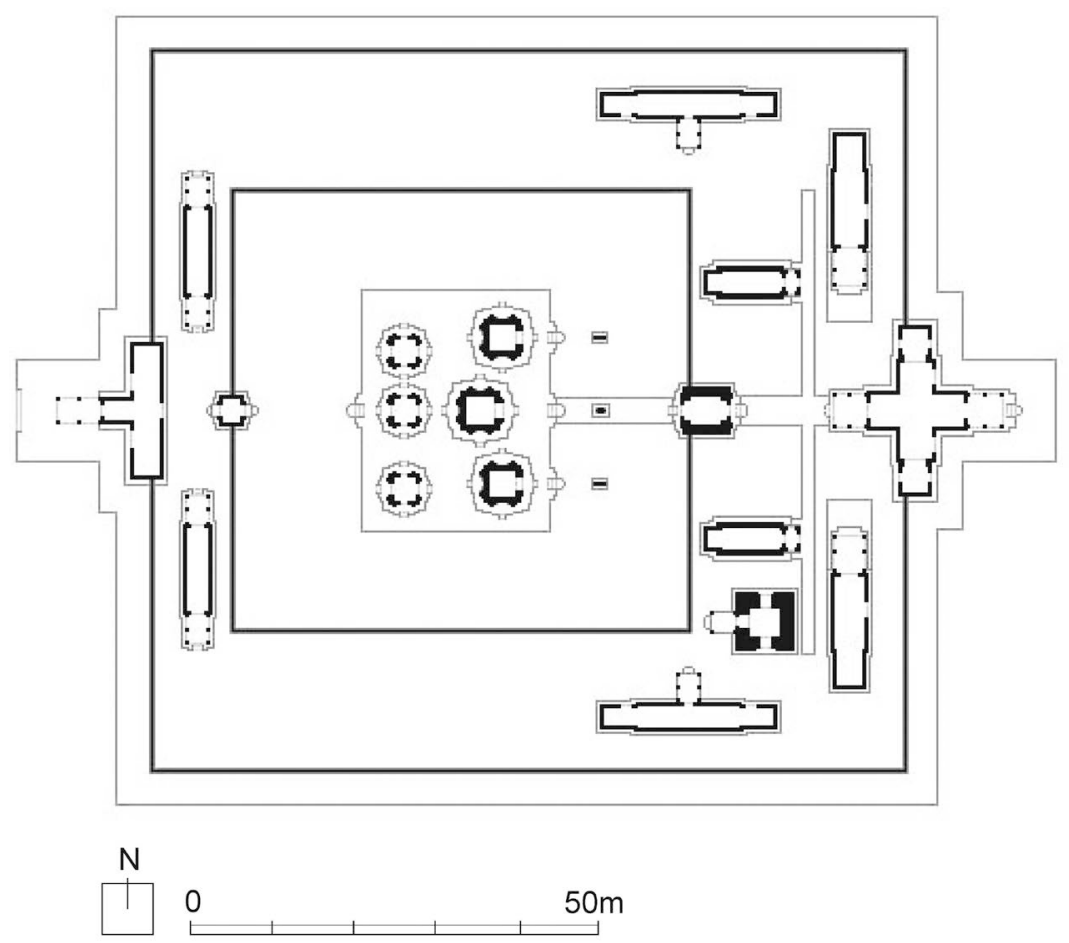

Figure 22. Plan of Preah Ko (source: École française d'Extrême-Orient).

the three complexes differ in terms of the special relationship between the enclosures, and the main axis running through the central shrine and east/west gopuras. In the case of Prasat Sambor, the main axis line splits the inner and middle enclosures into precisely even northern and southern sections. By contrast, 
in Prasat Yeai Poeun, the major axis is offset slightly to the north, creating a larger space in the southern parts of the enclosures than in the north. This asymmetric layout is also confirmed in Prasat Tao, except the north and south are reversed.

The layout of Prasat Sambor enclosures is less accurate than are those of the other two temple complexes. Specifically, in both the inner and middle enclosures, the southeastern corner of the perimeter is too far skewed outward from where it should be for the enclosure to form an exact square or rectangle. Likewise, the northwestern corner of the middle enclosure perimeter is too far skewed outward (Table 1). However, in terms of distance from the vertical axis, which intersects the main axis, the inner enclosure northern and southern walls are equidistant at $46.7 \mathrm{~m}$ from the center of the central shrine. Similarly, the middle enclosure lateral walls are equidistant from the central shrine at $89.3 \mathrm{~m}$ (Figure 7). These measurements imply that a main axis was deliberately plotted to evenly divided the space in the two enclosures.

In Prasat Yeai Poeun, the inner enclosure's eastern wall is $161 \mathrm{~m}$ long, but the point where the main axis intersects the center of the eastern gopura is situated $78.7 \mathrm{~m}$ northward and $82.3 \mathrm{~m}$ southward, putting it about $1.8 \mathrm{~m}$ north of the true midpoint of the wall. Regarding the outer enclosure, the eastern wall measures

Table 1. Measurement value and corresponding value to the unit value from the center of central shrine to each points of inner and middle enclosures in Prasat Sambor.

\begin{tabular}{|c|c|c|c|c|c|c|c|}
\hline & & \multicolumn{2}{|c|}{ Measurement value } & \multicolumn{2}{|c|}{$\begin{array}{l}\text { Corresponding value } \\
(\text { hasta } \times 6=2439 \mathrm{~mm})\end{array}$} & \multicolumn{2}{|c|}{ Theoretical corresponding value } \\
\hline & & $\mathrm{X}$ & $\mathrm{Y}$ & $\mathrm{X}$ & Y & $\mathrm{x}$ & $\mathrm{Y}$ \\
\hline & & (east direction) & (north direction) & (east direction) & (north direction) & (east direction) & (north direction) \\
\hline \multirow{8}{*}{ Inner Enclosure } & Center of east side & 0.000 & 46.627 & 0.0 & 19.1 & 0 & 19 \\
\hline & Northeast corner & 46.120 & 46.286 & 18.9 & 19.0 & 19 & 19 \\
\hline & Center of north side & 46.284 & 0.000 & 19.0 & 0.0 & 19 & 0 \\
\hline & Northwest corner & 46.465 & -46.584 & 19.1 & -19.1 & 19 & -19 \\
\hline & Center of west side & 0.000 & -46.766 & 0.0 & -19.2 & 0 & -19 \\
\hline & Southwest corner & -46.285 & -46.927 & -19.0 & -19.2 & -19 & -19 \\
\hline & Center of south side & -46.959 & 0.000 & -19.3 & 0.0 & -19 & 0 \\
\hline & Southeast corner & -47.650 & 46.953 & -19.5 & 19.3 & -19 & 19 \\
\hline \multirow{8}{*}{ Middle Enclosure } & Center of east side & 0.000 & 94.351 & 0.0 & 38.7 & 0 & 39 \\
\hline & Northeast corner & 88.283 & 93.701 & 36.2 & 38.4 & 37 & 39 \\
\hline & Center of north side & 89.332 & 0.000 & 36.6 & 0.0 & 37 & 0 \\
\hline & Northwest corner & 90.181 & -112.200 & 37.0 & -46.0 & 37 & -46 \\
\hline & Center of west side & 0.000 & -111.709 & 0.0 & -45.8 & 0 & -46 \\
\hline & Southwest corner & -87.919 & -111.398 & -36.0 & -45.7 & -37 & -46 \\
\hline & Center of south side & -89.348 & 0.000 & -36.6 & 0.0 & -37 & 0 \\
\hline & Southeast corner & -90.217 & 94.702 & -37.0 & 38.8 & -37 & 39 \\
\hline
\end{tabular}


$238 \mathrm{~m}$ in length, and the points where the wall intersects the main axis lie 117.6 $\mathrm{m}$ northward and $120.4 \mathrm{~m}$ southward, thus deviating from the midpoint by 1.4 $\mathrm{m}$ (Figure 11). In Prasat Tao, the length to northern wall of inner enclosure is $70.6 \mathrm{~m}$ from the central shrine, while the length to southern wall is $67.8 \mathrm{~m}$, denoting that the main axis line is passing $1.4 \mathrm{~m}$ south of the center of inner enclosure. Likewise, the length to northern wall of outer enclosure is $137.2 \mathrm{~m}$ from the central shrine while the length to southern wall is $132.0 \mathrm{~m}$, meaning that the main axis line is passing $2.6 \mathrm{~m}$ south of the center of precinct in the outer enclosure (Figure 15).

A well-known feature of classic Khmer temples is the main axis line is offset from the center of the enclosure. Typically, the main axis line is offset north, making the southern part of the enclosure more spacious than the northern part. However, in the case of Angkor Wat, whose front faces to the west, the main axis line is offset south, making the northern part of the enclosure more spacious. Similarly, in Preah Vihear, whose front faces north, the eastern segment of the enclosure is more spacious than the western segment. Thus, in most cases, if standing at the entrance of the temple complex and looking inward, the more spacious side of the enclosure would appear to the left. An anomaly is Prasat Thom. The main axis line passing the center of pyramid in the rearward enclosure is offset to the south. However, the main axis line in the frontward enclosure which contains several smaller shrines is offset to the north.

Mizoguchi et al. (2010a) has identified three approaches toward this offsetaxis design. The most common technique is to place the main axis line slightly north of the true center of the complex. Banteay Samre exemplifies this technique. The second technique involves an indirect approach. Specifically, the northern side of the complex is cropped off to bring the axis northward. An example of this technique is seen in Thommanon. The third technique is similarly indirect: the axis is brought northward by extending the enclosure southward. This technique is rare and Prasat Pram, in the ruins of Koh Ker, is one of the few examples. These results were derived from the detailed analysis of the layout of components based on the construction unit for planning the temple complex.

In the case of Prasat Yeai Poeun and Prasat Tao, they can be clearly confirmed offset of the main axis lines. However, it has not been possible to conduct a detailed analysis of the temple layout, because precise measurements of the location of each component is difficult due to the thick sedimentary soil accumulated in the precinct. It is nonetheless notable that, whereas the main axis in Prasat Sambor has not been offset, the main axis of the other two complexes has, implying the offsetting practice was first introduced during the time when these complexes were designed and it later became widely accepted practice in ancient Khmer architecture. The offsetting practice of the pyramidal temple of Angkor Wat and Bayon is widely recognized, and were precisely surveyed by the Japanese Government Team for Safeguarding Angkor. Additionally, other research teams surveyed Takeo and Pre Rup temples (Kojima \& Shigeeda, 2019). Further evidence comes from a plan of Phnom Bakheng drawn by the French School of 
the Far East (École française d'Extrême-Orient); the data confirms the main axis line is offset to the north. It remains unclear which state-temple was the first to adopt this practice as we currently lack precise data on earlier temples such as Bakong and Ak Yum. However, it is significant that this asymmetrical layout is not observed in the first state-temple, Prasat Sambor. The state-temple would be designed as the central axis of the state, and this concept was expressed by the true symmetrical composition of the temple complex at the beginning.

\section{Analyzing the Planning Technique behind Prasat Sambor}

In this section is discussed the planning technique of the layout in Prasat Sambor, and is based on the result of plane surveying. Detailed surveys of each component in Prasat Yeai Poeun and Prasat Tao are still difficult due to thick sedimentary soil accumulations, but in the case of Prasat Sambor, comprehensive data on the layout of every component is available because to past archaeological excavations and clearance (Shimoda et al. 2006; Shimoda \& Shimamoto, 2012). This data is sufficient to carry out an analysis of the planning technique of this temple complex.

Position of each structure were surveyed using a total station. In addition, manual measuring with a tape measure was also used for individual structures. After combining this measurement data, the precise plan of the temple complex was prepared by CAD system. In reality, the main axis of the temple complex is rotated about $2^{\circ} 10^{\prime \prime}$ counterclockwise, Figure 4 and Figure 7 rotate the axis back to fit the dimensions of the paper.

To understand the planning technique behind the temple layout, it is necessary to infer the construction unit which architects used designing this temple. For this task, we turn to a century of research on the construction units used in the ancient Khmer architecture beginning with Georges Cœdès. He estimated that 1 "hasta" is equal to $0.45 \mathrm{~m}$ based on the study of an inscription derived from a pyramidal structure Prang in Prasat Thom (Cœè̀s, 1924). This research was later continued by others. At the end of the last century, Eleanor Mannikka supposed the approximate length of a hasta to be either $450 \mathrm{~mm}$ or $436 \mathrm{~mm}$ (Mannikka, 1996). Drawing on these knowledges, Mizoguchi et al. conducted a series of analyses on the classic Khmer architecture in eastern Thailand, Angkor monuments, Koh Ker, and the isolated temples of Beng Mealea and Preah Vihear. The current results by his team indicated that the true length of a hasta was $412 \mathrm{~mm}$ (Mizoguchi et al., 2007, 2009, 2010a, 2010b, 2012). Based on the analysis of each shrine in Sambor Prei Kuk, the construction unit for individual shrines were estimated to be around $407.5 \mathrm{~mm}$ (Narui et al., 2019). The authors suggested that the construction unit varied between monuments, even though these monuments belong to the same temple complex. There is therefore some room for debate on their hypothesis. However, the conclusion of this article is coincident that the length of the construction unit was approximately $407 \mathrm{~mm}$.

The exact dimension of construction unit was calculated $406.5 \mathrm{~mm}$ through 
the analysis on the layout of the temple complex. This measure likely constituted 1 hasta. However, this scale would have been too small to design the entire temple complex, therefore it is likely that a measure of at least 6 hasta, or $2439 \mathrm{~mm}$, was widely used as the main unit for planning. Thusly, a 6-hasta length was defined as 1 unit $(1 \mathrm{u})$ in this article. Mizoguchi previously surmised that 4 hasta, or 1vyama, was used as an upper measurement unit in multiple temples. Such a scale does not fit in this case. Based on this construction unit, each dimension of the components in the middle enclosure were designed as shown below. For the central shrine, measurement values are presented along with the hasta and unit value. For other areas, however, measurement values are not presented because the dimension of four sides of components or each direction are not always precisely the same value. Table 1 shows the measurement value of each dimension of the inner and middle enclosures together with the corresponding unit value. The value of the outer enclosure was not presented in this article because this additional component to the original construction was from a later period, and would be constructed imprecisely.

- Diameter of the lingam in the central shrine (dimension of this principal object of worship was evaluated by the reconstructed pedestal): $1215 \mathrm{~mm}$ or 3 hasta.

- Length of the interior space of the central shrine: $4871 \mathrm{~mm}=12$ hasta $=2 \mathrm{u}$

- Full width of the exterior wall of the central shrine: $9686 \mathrm{~mm}=24$ hasta $=4 \mathrm{u}$

- Width of the exterior pilasters of the central shrine: 1 hasta

- Full width of the exterior base of the central shrine: $11,436 \mathrm{~mm}=28$ hasta

- Full width of the central terrace: $16 \mathrm{u}$

- Width of the central terrace base: $1 \mathrm{u}$

- Distance from foot of the central terrace base to perimeter of inner enclosure: $10 \mathrm{u}$

- Distance from centers of N3 and N4 to main axis line: $7 \mathrm{u}$

- Distance from wall of the corner shrines (N7 - N10) to perimeter of inner enclosure: $2 \mathrm{u}$

- Distance from east wall of the inner enclosure to east wall of the middle enclosure: $20 \mathrm{u}$

- Distance from west wall of the inner enclosure to west wall of the middle enclosure: $27 \mathrm{u}$

- Distance from north/south wall of the inner enclosure to north/south wall of the middle enclosure: $18 \mathrm{u}$

- Distance from centers of N11 and N12 to main axis line: $9 \mathrm{u}$

- Distance from center of N13 to major axis: $27 \mathrm{u}$

- Distances from centers of N15 and N22 to main axis line: $69 \mathrm{u}$ (both are situated $50 \mathrm{u}$ away from the north/south wall of the inner enclosure)

The dimensions derived from the construction units were identified in the various parts of the layout as above, and it is apparent that the basic framework of each components was designed using this unit. Although the previous re- 
searches by Mizoguchi identified the simple dimensions such as 10 times unit length to the full width of each enclosure, the dimensions in Prasat Sambor were not designed by the simple number of units. It is likely that locations of each component were emplaced from the center outward in this temple, and they carefully allocated the necessary religious space and visitor route among each facility. Thereby, the dimensions of the enclosure elements of Prasat Sambor would not be simplified the same as the temple complexes of Angkorian period which were previously studied by Mizoguchi.

As described above, the construction unit of Prasat Sambor was identified as $406.5 \mathrm{~mm}$ based on the precise plane survey. The longer dimension six times of the standard unit, $2439 \mathrm{~mm}$, would be used largely for practical planning and construction for the larger scaled temple complex. The unit length $406.5 \mathrm{~mm}$ is a similar dimension to the construction unit of $412 \mathrm{~mm}$ identified in multiple Angkorian temples. It was estimated that this standard length was authorized from the beginning of the pre-Angkorian period.

\section{Conclusion}

The temple during the pre-Angkorian period has been appraised as a primitive stage in the long history of classical Angkor architecture by Parmentier, who was the authoritative scholar in archaeological and architectural studies (Parmentier, 1927). Most of the pre-Angkorian temples were simple compositions consisting of a single building. However, current studies revealed that the diverse temple layouts which were developed in the later period were inherited from this earliest stage. In particular, various types of temple complexes were recorded in the royal city of Sambor Prei Kuk.

Within several temple complexes in this ancient city, the three large temples complexes were identified as the significant prototypes for the design and construction of later Khmer temples. These three temples with multiple enclosures have similar layout with multiple shrines and enclosures. However, closer inspection reveals notable differences in terms of the positioning of the central shrine within the enclosure, the design of the central shrine, and position of lateral gopura in the enclosure wall. These features were maintained in the main streams of the architectural lineage of the Angkorian period.

Prasat Sambor, with its layout that distributes symmetry out evenly in four directions from the central shrine which was elevated by central terrace, was the prototype of the pyramidal state-temple of later periods. Prasat Yeai Poeun and Prasat Tao are prototypes of a series of temple designs that extend lengthways to emphasize the frontal perspective and depth of the precinct. This latter series is further divided into two subcategories delineated by the criterion of whether the enclosure walls have lateral gopura. Prasat Yeai Poeun is the prototype of the temple with lateral gopura and Prasat Tao is the temple without lateral gopura. These three temple configurations continued to develop as separate architectural genres for many years until the late Angkorian period when they fused together 
creating an even more complex design.

These three temples have another difference feature in the layout of the main axis line. The main axis of Prasat Sambor splits the space in enclosures evenly, while the main axis of Prasat Yeai Poeun is offset to the north to create extra space in the southern part of the enclosures, and main axis of Prasat Tao is offset to the south. Asymmetric layout the same as Prasat Yeai Poeun would be commonly seen in many temples in later periods. Prasat Sambor would be designed as the state-temple which is the omphalos of the ruled territory, and the central shrine was constructed at the exact center in the precinct as the symbolic monument of kingdom and rule.

From the enshrined deity statues of several shrines, this state-temple epitomized the representation of integrated Hinduism cosmology, Trimurti; the central area of Prasat Sambor was dedicated to Shiva and his dependents, and a shrine at the south of this temple, N20, was dedicated to Brahma. The enshrined deity at the north, N16, has not been identified, but it was highly possible the house of Vishnu. This state-temple would be the most significant facility for national religious worship, and Hindu deities were gathered here as a pantheon of gods to bestow their blessings across the entire Khmer kingdom. Thus, it was clearly identified the different concept and status between Prasat Sambor and Prasat Yeai Poeun. Under king Isanavarman I the earliest temple complex with multiple enclosures were located in proximity to each other. It is estimated that one was constructed as a state-temple for symbolizing royal authority and the other was constructed as temple to ancestral deities including the king's predecessor and king himself. This functional division would be inherited by the early stage of Angkorian state temples. A prime example of such inheritance is a pair of temples identified as Bakong and Preah Ko in Harihararaya.

The dimensional analysis revealed that the construction unit of Prasat Sambor was a length of $406.5 \mathrm{~mm}$. This is not too different from the hasta (approximately $412 \mathrm{~mm}$ ) that was identified in the various temples in the Angkorian period. It also revealed that the dimensions for the various parts of the complex were designed based on a measure amounting to six multiples of $406.5 \mathrm{~mm}$. Furthermore, each component would be placed from the center outward for allocating the necessary space of each facility and route for the religious ceremonies.

An important task for historians of Khmer architecture is to contextualize the developments in temple design within a broad span of history that encompasses pre-Angkorian times to the end of the Angkorian period. A plethora of ruins have been recorded, but owing in part to regional variation in these ruins, it is far from easy to consolidate the information into a linear timeline that shows the phases of development. However, among all the various ruins, the state-temple stands out in that it represents a highly canonical style, one that best exemplified each period. It can therefore be seen that the state-temples were key historical waypoints that help us trace the broad trajectory of this architectural history. Prasat Sambor marked the starting point in this canonical architectural lineage. 
As such, the layout of this temple complex became an important template that guided future architectural developments. Therefore, when it comes to the research of Angkorian architecture from perspective points of views, it is essential to include the original composition and appearance of Prasat Sambor. In addition, the comparison analysis between earliest and later state-temples will contribute to our further understand of the chronological and genealogical development of Angkorian architecture.

\section{Acknowledgements}

This study was conducted as part of the Conservation Project of Sambor Prei Kuk directed by Nakagawa Takeshi. The project was supported financially by Sumitomo Foundation and JSPS KAKENHI Grant Number JP 24686068, 17H01628. We would like to thank Robert McCarthy for his English editing. The author expresses my deep gratitude to HE Phann Nady, General Director of National Authority for Sambor Prei Kuk (NASPK), Mr. Chan Vitharong, Director of Department of Site, Archaeology and Conservation of NASPK, and Dr. So Sokuntheary, Professor of Norton University for their contribution to this study.

\section{Conflicts of Interest}

The author declares no conflicts of interest regarding the publication of this paper.

\section{References}

Chhum, M., Shimoda, I., \& Nakagawa, T. (2013). Construction and Utilization Dating of Temples Based on Existing Remains Inside the City Compound-Structure of the Ancient Khmer City of Isanapura (Part I). Journal of Architecture and Planning, 78, 18651874. https://doi.org/10.3130/aija.78.1865

Cœdès, G. (1924). Inscription du Cambodge, Vol. 1, Hanoi. Paris, Études Cambodgiennes. Bulletin de l'École Française d'Extrême-Orient, 24, 69-71.

Codès, G. (1965). Le Rôle de la Pyramide de Koh Ker dans l’Évolution du Temple-Montagne Khmer. Paranavitana, Felicitation Volume, 61-66.

Goloubew, V. (1927). Chronique. Sambor Prei Kuk. Bulletin de l'École Française d’ Extrême-Orient, 27, 489-492.

Groslier, B. P. (1981). Introduction to the Ceramic Wares of Angkor. In D. Stock (Ed.), Khmer Ceramics: 9th-14th Century (pp. 9-39). Singapore: Oriental Ceramic Society.

Kojima, Y., \& Shigeeda, Y. (2019). On the Measurements of the Foundation and Temple Layout of Ta Kev in Angkor Period, Basic Study on the Temple Complex and the Construction Method of Khmer Architecture. Journal of Architecture and Planning, 759, 1247-1257. https://doi.org/10.3130/aija.84.1247

Kubo, S., Nagumo, N., Chhum, M., \& Shimoda, I. (2016). Radiocarbon Ages and Stratigraphy in the City Area of the Sambor Prei Kuk Pre-Angkor Archaeological Site, Cambodia. Bulletin of the Graduate School of Education of Waseda University, 26, 43-55.

Kubo, S., Shimamoto, S., Nagumo, N., Yamagata, M., Him, S., So, S., Chang, V., Lun, V., Shimoda, I., \& Nakgawa, T. (2012). Geomorphology, Archaeostratigraphy, and 14C Ages of Sambor Prei Kuk Pre-Angkorean Site, Central Cambodia. Bulletin of the Gradu- 
ate School of Education of Waseda University, 22, 73-90.

Mannikka, E. (1996). Angkor Wat Time, Spaces, and Kingship. Honolulu, HI: University Hawaii Press.

Mauger, H. (1937). Le Phnom Bayan, IK 3. Bulletin de l'École Française d'ExtrêmeOrient, 37, 239-262. https://doi.org/10.3406/befeo.1937.5352

Miriam, S. (2003). Angkor Borei and the Archaeology of Cambodia's Mekong Delta. J. Khoo (Ed.), Art and Archaeology of Fu Nan: Pre-Khmer Kingdom of the Lower Mekong Valley (pp. 87-106). Bangkok: Orchid Books.

Mizoguchi, A., Nakagawa, T., Asano, T., \& Saito, N. (2007). On the Dimensional Plan of the Complex in Thommanon and Banteay Samre-Study on the Dimensional Plan and the Planning Method of Khmer Architecture No. 1. Journal of Architecture and Planning, 72, 131-138. https://doi.org/10.3130/aija.72.131 2

Mizoguchi, A., Nakagawa, T., Sato, K., \& Shimoda, I. (2010a). The Ancient Khmer's Dimensional Planning at the Prasat Thom in Koh Ker-Study on the Dimensional Plan and the Planning Method of Khmer Architecture No. 5. Journal of Architecture and Planning, 75, 1751-1759. https://doi.org/10.3130/aija.75.1751

Mizoguchi, A., Nakagawa, T., Sato, K., \& Shimoda, I. (2010b). The Ancient Khmer's Dimensional Planning at the Prasat Pram in Koh Ker-Study on the Dimensional Plan and the Planning Method of Khmer Architecture No. 4. Journal of Architecture and Planning, 75, 1273-1278. https://doi.org/10.3130/aija.75.1273

Mizoguchi, A., Nakagawa, T., Sato, K., Shimoda, I., \& Furukawa, D. (2009). The Ancient Khmer's Dimensional Planning at the Prang in Koh Ker-Study on the Dimensional Plan and the Planning Method of Khmer Architecture No. 3. Journal of Architecture and Planning, 74, 1449-1455. https://doi.org/10.3130/aija.74.1449

Mizoguchi, A., Nakagawa, T., Sato, K., Shimoda, I., \& Momose, J. (2012). The Ancient Khmer's Dimensional Planning at the Beng Mealea-Study on the Dimensional Plan and the Planning Method of Khmer Architecture No. 6. Journal of Architecture and Planning, 77, 157-164. https://doi.org/10.3130/aija.77.157

Narui, I., Nakagawa, T., \& Koiwa, M. (2019). On the Dimensional Plan in Prasat Sambor Monuments in Sambor Prei Kuk Monuments-Study on the Technique of Planning Methods in Times of Pre-Angkor Period (1). Journal of Architecture and Planning, 84, 1463-1472. https://doi.org/10.3130/aija.84.1463

Parmentier, H. (1927). L'art Khmèr Primirif (Two Volumes). Vol. 21-22, Paris: École Française d'Extrême-Orient.

Santoni, M., \& Hawixbrock, C. (1998). Laos. Fouilles et Prospections Dans la Région de Vat Phu (Province de Champassak. Sud du Laos). Bulletin de P École Française d’ EXtrême-Orient, 85, 387-405. https://doi.org/10.3406/befeo.1998.2560

Shimamoto, S., Yamamoto, N., \& Nakagawa, N. (2008). Reexamination on the Dating of Ceramics of Sambor Prei Kuk Found by B. P. Groslier. Journal of Southeast Asian Archaeology, 28, 47-60.

Shimoda, I., \& Nakagawa, T. (2015). Diversity of the Primitive Khmer Architecture in Sambor Prei Kuk. Journal of Architecture and Planning, 80, 2923-2933.

Shimoda, I., \& Shimamoto, S. (2012). Spatial and Chronological Sketch of the Ancient City of Sambor Prei Kuk. Aséanie, 30, 11-74.

Shimoda, I., Him, S., Seng, K., Chan, V., Chhum, M., So, S., \& Nakagawa, T. (2006). Preliminary Report on the Excavation Survey at the Prasat Sambor, Sambor Prei Kuk, 20042005. Journal of Southeast Asian Archaeology, 26, 117-145.

Shimoda, I., Sugasawa, Y., Yonenobu, H., \& Tabata, Y. (2015). Research on the Active 
Habitation Period of the Ancient Khmer City ISANAPURA. Journal of Southeast Asian Archaeology, 35, 1-14.

Shimoda, I., Uchida, E., \& Tsuda, K. (2019). Estimated Construction Order of the Major Shrines of Sambor Prei Kuk Based on an Analysis of Bricks. Heritage, 2, 1941-1959. https://doi.org/10.3390/heritage2030118 